\title{
Selective Synthesis and Photophysical Properties of Phosphorescent Heteroleptic Iridium(III) Complexes with two Different Bidentate Groups and two Different Monodentate Ligands
}

\author{
Miguel A. Esteruelas, * Enrique Oñate, and Adrián U. Palacios \\ Departamento de Química Inorgánica, Instituto de Síntesis Química y Catálisis Homogénea (ISQCH), Centro de Innovación \\ en Química Avanzada (ORFEO - CINQA), Universidad de Zaragoza - CSIC, 50009 Zaragoza, Spain \\ Supporting Information Placeholder
}

\begin{abstract}
Rational synthetic procedures for the preparation of phosphorescent heteroleptic iridium(III) complexes, with controlled stereochemistry, of general formula $\operatorname{IrX}\left\{\kappa^{2}-N, C\right.$ - (qui- $\left.\left.\mathrm{C}_{6} \mathrm{H}_{4}\right)\right\}(\mathrm{acac})\left(\mathrm{P}^{i} \mathrm{Pr}_{3}\right)$ and their photophysical properties are reported. The $\mathrm{d}^{4}$-pentahydride $\mathrm{IrH}_{5}\left(\mathrm{P}^{i} \operatorname{Pr}_{3}\right)_{2}$ (1) promotes the chelate-supported C-H bond activation of 2-phenylquinoline to give $\operatorname{IrH}_{2}\left\{\kappa^{2}-N, C\right.$ (qui- $\left.\left.\mathrm{C}_{6} \mathrm{H}_{4}\right)\right\}\left(\mathrm{P}^{i} \mathrm{Pr}_{3}\right)_{2}$ (2), which affords the five-coordinate monohydride $\left[\operatorname{IrH}\left\{\kappa^{2}-N, C\right.\right.$ - $\left(\right.$ qui- $\left.\left.\left.\mathrm{C}_{6} \mathrm{H}_{4}\right)\right\}\left(\mathrm{P}^{i} \mathrm{Pr}_{3}\right)_{2}\right] \mathrm{BF}_{4}(\mathbf{3})$ by protonation with $\mathrm{HBF}_{4}$. Treatment of 3 with potassium acetylacetonate (Kacac) yields the hydrido-target compound $\operatorname{IrH}\left\{\kappa^{2}-N, C\right.$-(qui$\left.\left.\mathrm{C}_{6} \mathrm{H}_{4}\right)\right\}(\mathrm{acac})\left(\mathrm{P}^{i} \mathrm{Pr}_{3}\right)(4)$. Phenylacetylene and acetylene insert into the $\mathrm{Ir}-\mathrm{H}$ bond of $\mathbf{3}$ to form the five-coordinate alkenyl derivatives $\left[\operatorname{Ir}(E-\mathrm{CH}=\mathrm{CHR})\left\{\kappa^{2}-N, C\right.\right.$ - $\left(\right.$ qui- $\left.\left.\left.\mathrm{C}_{6} \mathrm{H}_{4}\right)\right\}\left(\mathrm{P}^{i} \mathrm{Pr}_{3}\right)_{2}\right] \mathrm{BF}_{4}(\mathrm{R}=\mathrm{Ph}(\mathbf{5}), \mathrm{H}(\mathbf{6}))$. Similarly to 3, complexes 5 and 6 react with $\mathrm{K}(\mathrm{acac})$ to give $\operatorname{Ir}(E-\mathrm{CH}=\mathrm{CHR})\left\{\kappa^{2}-N, C-\left(\right.\right.$ qui- $\left.\left.\mathrm{C}_{6} \mathrm{H}_{4}\right)\right\}(\mathrm{acac})\left(\mathrm{P}^{i} \mathrm{Pr}_{3}\right)(\mathrm{R}=\mathrm{Ph}(\mathbf{7}), \mathrm{H}(\mathbf{8}))$. The chloride counterpart of 4,7 and 8 has been obtained starting from $\mathrm{IrCl}_{3}(\mathrm{tht})_{3}(\mathbf{9}$, tht $=$ tetrahydrotiophene). Treatment of this compound with triisopropylphosphine and 2phenylquinoline leads to the five-coordinate species $\operatorname{IrCl}_{2}\left\{\kappa^{2}-N, C\right.$ - $\left(\right.$ qui- $\left.\left.\mathrm{C}_{6} \mathrm{H}_{4}\right)\right\}\left(\mathrm{P}^{i} \mathrm{Pr}_{3}\right)(\mathbf{1 0})$. The use of triphenylphosphine instead of triisopropylphosphine affords the $\mathrm{PPh}_{3}$-analogous $\mathrm{IrCl}_{2}\left\{\kappa^{2}-N, C\right.$ - $\left(\right.$ qui- $\left.\left.\mathrm{C}_{6} \mathrm{H}_{4}\right)\right\}\left(\mathrm{PPh}_{3}\right)(\mathbf{1 1})$. Complexes 10 and 11 react with $\mathrm{K}(\mathrm{acac})$ to give $\operatorname{IrCl}\left\{\kappa^{2}-N, C\right.$ - $\left(\right.$ qui- $\left.\left.\mathrm{C}_{6} \mathrm{H}_{4}\right)\right\}(\mathrm{acac})\left(\mathrm{PR}_{3}\right)\left(\mathrm{PR}_{3}=\mathrm{P}^{i} \mathrm{Pr}_{3}(\mathbf{1 2}), \mathrm{PPh}_{3}(\mathbf{1 3})\right)$. The six coordinate compounds 4, 7, 8, 12 and 13 are yelloworange emissive upon photoexcitation with short life-times and quantum-yields increasing in the sequence $\mathbf{7}(\mathrm{CH}=\mathrm{CHPh})<\mathbf{1 2}(\mathrm{Cl})$ $<\mathbf{8}\left(\mathrm{CH}=\mathrm{CH}_{2}\right)<\mathbf{4}(\mathrm{H})$, as the contribution of the metal center to the HOMO of the complexes also increases.
\end{abstract}

\section{INTRODUCTION}

The nature and energy of the excited states in $\mathrm{d}^{6}$-complexes can be manipulated by deliberate chemical synthesis. As a consequence, there is a growing interest in phosphorescent iridium(III) complexes, which can reach high quantum efficiency and short lifetimes and further show a facile color tuning. ${ }^{1}$ With some exception, ${ }^{2}$ they are mononuclear compounds, which can be grouped in two big classes: homoleptic species and heteroleptic complexes. Homoleptic species are ions or molecules. Ions contain two equal neutral or monoanionic N,N,N-tridentate ligands coordinated to an iridium(III) center, ${ }^{3}$ whereas the molecules are formed by an iridium(III) core surrounded by three equal monoanionic bidentate ligands, which usually display $\mathrm{N}$ - and $\mathrm{C}$-donor atoms with a coordination disposition affording a five- or six-membered metalacycle. ${ }^{4}$ Heteroleptic complexes also include ions and molecules. However, in this case, they contain at least two different ligands. ${ }^{5}$

Heteroleptic iridium(III) complexes can be tailored to express specific luminescent properties. The straightforward manner in which these properties can be tuned has positioned this type of compounds at the forefront of modern photochemistry. Although salts can be also employed for OLED ${ }^{6}$ applications, in addition to the light-emitting electrochemical cell (LEC) technology, ${ }^{7}$ neutral compounds are usually used as a emitter for device fabrication. ${ }^{8}$ As a consequence, the neutral iridium(III) complexes have awakened more interest than the iridium salts.
The metal center of these octahedral compounds coordinates from 2 to 5 different elements as donor atoms. According to the number of donated electrons by each ligand and its denticity, $(\mathrm{m}=$ monodentate, $\mathrm{b}=$ bidentate, $\mathrm{t}=$ tridentante $)$ the neutral phosphorescet iridum (III) complexes can be classified into: $\quad\left[5 \mathrm{t}+4 \mathrm{t}^{\prime}\right],{ }^{3 \mathrm{c}, 9} \quad[5 \mathrm{t}+3 \mathrm{~b}+1 \mathrm{~m}],{ }^{10} \quad\left[3 \mathrm{~b}+3 \mathrm{~b}+3 \mathrm{~b}\right.$ '], ${ }^{11}$ $[3 b+3 b '+3 b '],,{ }^{12}, \quad[3 b+3 b+2 m+1 m '],{ }^{13}$ $\left[3 b+2 m+2 m+1 m^{\prime}+1 m^{\prime \prime},{ }^{14} \quad\left[4 b+3 b^{\prime}+1 m+1 m\right]\right.$, $\left[4 b+3 b^{\prime}+1 m+1 m^{\prime}\right],\left[4 b+3 b^{\prime}+2 b\right.$ ' $],{ }^{15}$ species. For each composition, several isomers with different stereochemistries are possible, increasing the number of isomers as increases the number of different donor atoms around the iridium(III) core. Each isomer has its own photophysical properties. As a result, the selective synthesis of the wished isomer is necessary. Thus, the development of procedures for the selective preparation of specific isomers is certainly a challenge of the highest level.

The difficulty of preparing selectively a particular isomer increases as the number of different ligands around the metal center also increases. This has made of the family of phosphorescent heteroleptic iridium(III) complexes $[3 b+3 b+3 b$ '] the largest with great difference, since it is the most easy of obtaining via $(3 \mathrm{~b})_{2}$-chloride dimers. As a consequence, the synthetic efforts to achieve a wide range of color have been focused on the ligand design, instead in the search of new structures. Significantly less attention has received the relationship 


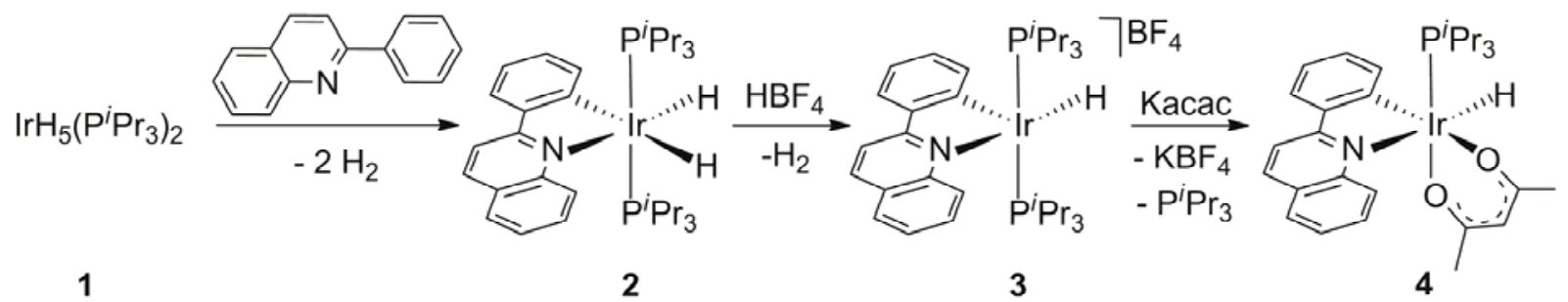

ligand-structure-quantum efficiency. ${ }^{16}$ In an effort to develop synthetic procedures for the selective preparation of phosphorescent iridium(III) complexes, with a high number of different donor atoms around the metal center, and interested in investigating the influence on the color and on quantum efficiency of usual ligands in organometallics, but less frequent in photophysical studies such as hydride and alkenyl, ${ }^{17}$ we decided to prepare a novel [ $\left.3 b+3 b^{\prime}+2 m+1 m^{\prime}\right]$ family of iridium(III) compounds. This paper describes the synthetic procedures for the selective preparation of the isomer shown in Chart 1 of complexes $\operatorname{IrX}\left\{\kappa^{2}-N, C\right.$ - $\left(\right.$ qui- $\left.\left.\mathrm{C}_{6} \mathrm{H}_{4}\right)\right\}($ acac $)\left(\mathrm{P}^{i} \mathrm{Pr}_{3}\right) \quad(\mathrm{X}=\mathrm{H}$, $\mathrm{CH}_{2}=\mathrm{CH}, \mathrm{PhCH}=\mathrm{CH}, \mathrm{Cl}$ ) and shows the relationship between the ligand $\mathrm{X}$ and the quantum efficiency.

\section{Chart 1. Target Complexes in this Study}

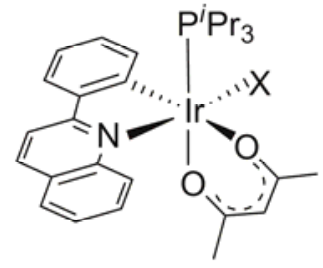

\section{$\mathrm{X}=\mathrm{H}, \mathrm{CH}=\mathrm{CHPh}, \mathrm{CH}=\mathrm{CH}_{2}, \mathrm{Cl}$}

\section{RESULTS AND DISCUSSION}

Hydride Complex. Polyhydrides of platinum group metals have been proven to perform a wide range of $\sigma$-bond activation reactions, ${ }^{18}$ including the cleavage of $\mathrm{C}-\mathrm{H}$ bonds, in particular chelate-supported cyclometalation reactions. ${ }^{19}$ We have previously used this ability of polyhydrides to prepare several types of phosphorescent osmium(IV) ${ }^{17}$ and osmium(II $)^{8 \mathrm{a}, 20}$ complexes, by means of sequential $\sigma$-bond activation reactions, starting from the $\mathrm{d}^{2}$-hexahydride $\mathrm{OsH}_{6}\left(\mathrm{P}^{i} \mathrm{Pr}_{3}\right)_{2}$. In a consistent manner with the behavior of this hexahydride, we have also observed that the $d^{4}$-pentahydride $\operatorname{IrH}_{5}\left(\mathrm{P}^{i} \mathrm{Pr}_{3}\right)_{2}$ (1) promotes the chelate NHC-supported aryl C-H bond activation of phenyl substituted bis(azolium) salts, to afford different types of dinuclear iridium-NHC complexes containing metalated aryl groups. ${ }^{21}$ In view of these precedents, we decided to employ complex 1 to perform the direct cyclometalation of 2phenylquinoline and to subsequently generate the hydridetarget compound as shown in Scheme 1.

Treatment of toluene solutions of $\mathbf{1}$ with 1.0 equiv of the heterocycle, under reflux, for $24 \mathrm{~h}$ affords the iridium(III) dihydride $\operatorname{IrH}_{2}\left\{\kappa^{2}-N, C\right.$-(qui- $\left.\left.\mathrm{C}_{6} \mathrm{H}_{4}\right)\right\}\left(\mathrm{P}^{i} \mathrm{Pr}_{3}\right)_{2}$ (2), as expected. Its formation is the result of the release of two hydrogen molecules and the quinolyl-supported ortho- $\mathrm{CH}$ bond activation of the phenyl substituent of the amine. This complex was isolated as an orange solid in $67 \%$ yield and characterized by X-ray diffraction analysis. Figure 1 shows a view of the structure. The coordination polyhedron around the iridium atom can be rationalized as a distorted octahedron with trans-phosphines $\left.(\mathrm{P}(1)-\mathrm{Ir}-\mathrm{P}(2))=162.24(2)^{\circ}\right)$. The perpendicular plane is formed by the chelate ligand, which acts with a $\mathrm{C}(1)-\mathrm{Ir}-\mathrm{N}(1)$ bite angle of $77.67(9)^{\circ}$, and the hydrides. The $\mathrm{Ir}-\mathrm{C}(1)$ and Ir$\mathrm{N}(2)$ bond lengths of 2.079(3) and 2.209(2) $\AA$, respectively, compare well with the reported ones for related heterometalacycles. ${ }^{22}$ In agreement with the presence of two inequivalent hydride ligands in the molecule, the ${ }^{1} \mathrm{H}$ NMR spectrum in benzene- $d_{6}$ shows two high field resonances at -12.17 and $21.20 \mathrm{ppm}$, which appear as double triplets with a H-H coupling constant of $5.0 \mathrm{~Hz}$ and H-P coupling constants of 20.6 and $18.2 \mathrm{~Hz}$, respectively. In the ${ }^{13} \mathrm{C}\left\{{ }^{1} \mathrm{H}\right\}$ NMR spectrum, the most noticeable feature is the presence of a triplet $\left({ }^{2} J_{\mathrm{C}-\mathrm{P}}=7.0\right.$ $\mathrm{Hz}$ ) at $181.5 \mathrm{ppm}$, corresponding to the metalated carbon atom of the chelate ligand. The equivalent phosphines give rise to a singlet at $25.5 \mathrm{ppm}$, in the ${ }^{31} \mathrm{P}\left\{{ }^{1} \mathrm{H}\right\}$ NMR spectrum.

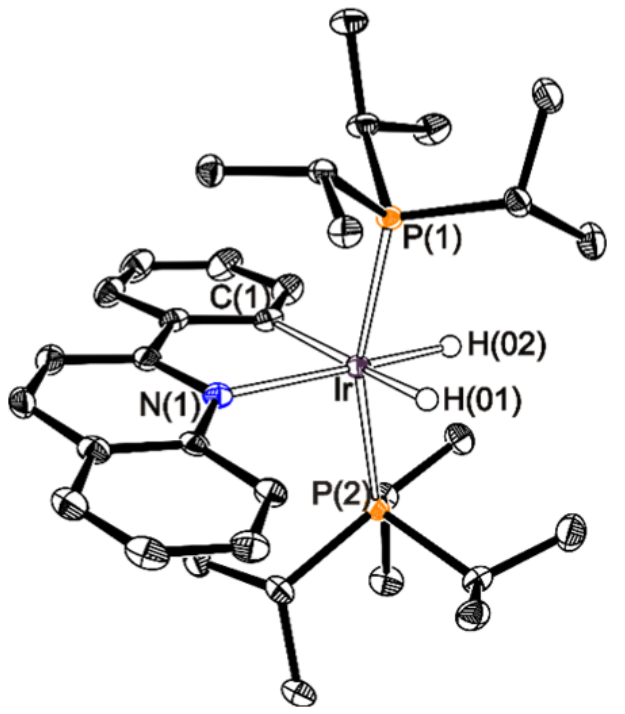

FIGURE 1. ORTEP diagram of complex $2(50 \%$ probability ellipsoids). Hydrogen atoms (except the hydrides) are omitted for clarity. Selected bond lengths $(\AA)$ and angles $(\mathrm{deg})$ : $\operatorname{Ir}-\mathrm{C}(1)=$ 2.079(3), $\operatorname{Ir}-\mathrm{N}(1)=2.209(2), \operatorname{Ir}-\mathrm{P}(1)=2.3167(7), \operatorname{Ir}-\mathrm{P}(2)=$ 2.3041(7), C(1)-Ir-N(1) = 77.67(9), P(1)-Ir-P(2) = 162.24(2).

Complex 2 is a Brønsted base. At least one of the hydride ligands is responsible for this character. ${ }^{23}$ Thus, the addition of 1.0 equiv of $\mathrm{HBF}_{4} \cdot \mathrm{OEt}_{2}$ to diethyl ether solutions of 2 produces the release of molecular hydrogen, as a result of the protonation of the basic hydride, and the formation of the fivecoordinate monohydride derivative $\left[\operatorname{IrH}\left\{\kappa^{2}-N, C\right.\right.$-(qui$\left.\left.\left.\mathrm{C}_{6} \mathrm{H}_{4}\right)\right\}\left(\mathrm{P}^{i} \mathrm{Pr}_{3}\right)_{2}\right] \mathrm{BF}_{4}$ (3). The salt was isolated as an orange solid in $59 \%$ yield and characterized by X-ray diffraction 
analysis. Figure 2 shows a view of the cation. The structure proves the unsaturated character of the metal center. The geometry around the iridium atom can be rationalized as a distorted square pyramid with the metalated carbon atom of the chelate group in the apex. At the base, the nitrogen atom lies trans to the hydride $\left(\mathrm{N}(1)-\operatorname{Ir}-\mathrm{H}(01)=176.4(13)^{\circ}\right)$ along with the phosphines, which are also trans disposed $(\mathrm{P}(1)-\mathrm{Ir}-\mathrm{P}(2))=$ $\left.159.70(3)^{\circ}\right)$. The four donor atoms forming the base and the metal center are approximately in a plane. Although the cation is undoubtedly a 16-valence electrons species, in the sixth position of the formal octahedron, the iridium atom is wellshielded by two methyl groups, one of each phosphine, and the homocyclic ring of the quinolyl group. The shielding effect of the methyl groups is supported by the bending of the P(1)-Ir$\mathrm{P}(2)$ angle, which markedly deviates from the ideal value of $180^{\circ}$. The shielding effect may also explain the surprising stability of this unsaturated iridium(III) cation which does not contain any $\pi$-donor ligand. The $\operatorname{Ir}-\mathrm{C}(1)$ bond length of 1.984(3) $\AA$ as well as the Ir-N(1) distance of 2.158(3) $\AA$ compare well with the respective parameters of 2 . The ${ }^{1} \mathrm{H},{ }^{13} \mathrm{C}\left\{{ }^{1} \mathrm{H}\right\}$ and ${ }^{31} \mathrm{P}\left\{{ }^{1} \mathrm{H}\right\}$ NMR spectra of the salt, in dichlorometane- $d_{2}$, at room temperature are consistent with the structure shown in Figure 2. In the ${ }^{1} \mathrm{H}$ NMR spectrum, the hydride resonance appears as a triplet $\left({ }^{2} J_{\mathrm{H}-\mathrm{P}}=16.1 \mathrm{~Hz}\right)$ at $-12.88 \mathrm{ppm}$. The ${ }^{13} \mathrm{C}\left\{{ }^{1} \mathrm{H}\right\}$ NMR spectrum contains the signal corresponding to the metalated carbon atom of the chelate ligand at $121.3\left(\mathrm{t},{ }^{2} J_{\mathrm{C}-}\right.$ $\mathrm{P}=6.2 \mathrm{~Hz}) \mathrm{ppm}$, shifted about $60 \mathrm{ppm}$ towards higher field with regard to that of 2 . The ${ }^{31} \mathrm{P}\left\{{ }^{1} \mathrm{H}\right\}$ NMR spectrum shows a singlet at $27.9 \mathrm{ppm}$ for the equivalent phosphines.

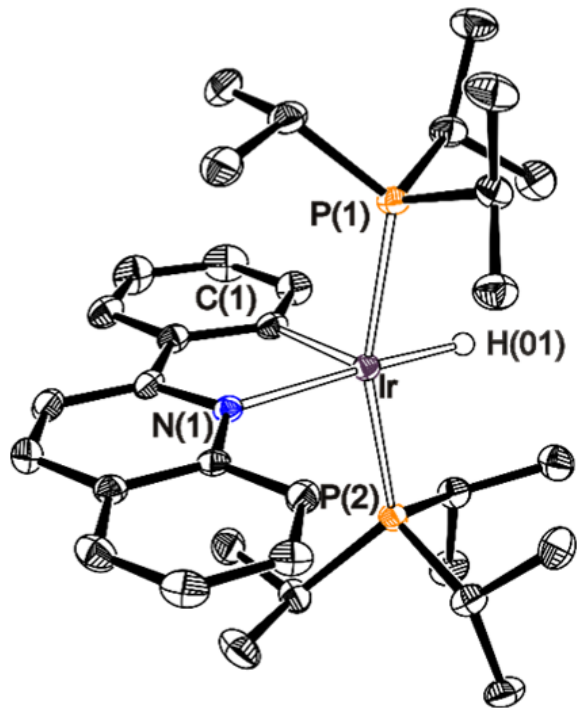

FIGURE 2. ORTEP diagram of cation of complex 3 (50\% probability ellipsoids). Hydrogen atoms (except the hydride) are omitted for clarity. Selected bond lengths $(\AA)$ and angles (deg): Ir$\mathrm{C}(1)=1.984(3), \operatorname{Ir}-\mathrm{N}(1)=2.158(3), \operatorname{Ir}-\mathrm{P}(1)=2.3470(9), \operatorname{Ir}-\mathrm{P}(2)=$ 2.3487(8), C(1)-Ir-N(1) = 79.83(12), P(1)-Ir-P(2) = 159.70(3).

The six-coordination number for $\mathbf{3}$ can be achieved by reaction with potassium acetylacetonate $(\mathrm{K}(\mathrm{acac}))$. The entry of the new ligand produces the release of one of the phosphines. Thus, the addition of 1.1 equiv of $\mathrm{K}(\mathrm{acac})$ to tetrahydrofuran solutions of 3 selectively yields the hydride-target compound $\operatorname{IrH}\left\{\kappa^{2}-N, C\right.$ - $\left(\right.$ qui- $\left.\left.\mathrm{C}_{6} \mathrm{H}_{4}\right)\right\}(\mathrm{acac})\left(\mathrm{P}^{i} \mathrm{Pr}_{3}\right) \quad(4)$, after $12 \mathrm{~h}$, under reflux. Complex 4 was isolated as a yellow solid in $75 \%$ yield. Its stereochemistry was determined by X-ray diffraction analysis. Figure 3 shows a view of the structure. The coordination polyhedron around the iridium atom can be rationalized as a distorted octahedron with the hydride ligand disposed trans to the nitrogen atom of the quinolyl group $(\mathrm{H}(01)-\mathrm{Ir}-\mathrm{N}(1)=$ $\left.173.7(11)^{\circ}\right)$. The perpendicular plane is formed by the acac ligand, the phosphine disposed trans to $\mathrm{O}(2)(\mathrm{P}(1)-\mathrm{Ir}-\mathrm{O}(2)=$ $\left.170.94(5)^{\circ}\right)$ and the metalated carbon atom of the phenyl group disposed trans to $\mathrm{O}(1)\left(\mathrm{C}(1)-\mathrm{Ir}-\mathrm{O}(1)=176.17(10)^{\circ}\right)$. The Ir$\mathrm{C}(1)$ and Ir-N(1) bond lengths of 1.990(3) and 2.228(2) A,, respectively, compare well with those of 2 and 3 . In the ${ }^{1} \mathrm{H}$ NMR spectrum, in dichloromethane- $d_{2}$, at room temperature, the hydride resonance is observed at $-19.80 \mathrm{ppm}$ as a doublet with a H-P coupling constant of $24.3 \mathrm{~Hz}$, whereas the resonance due to the metalated carbon atom of the phenyl group appears at $150.8 \mathrm{ppm}$ in the ${ }^{13} \mathrm{C}\left\{{ }^{1} \mathrm{H}\right\}$ NMR Spectrum, also as a doublet $\left({ }^{2} J_{\mathrm{C}-\mathrm{P}}=8.5 \mathrm{~Hz}\right)$. The ${ }^{31} \mathrm{P}\left\{{ }^{1} \mathrm{H}\right\}$ NMR spectrum shows a singlet at $12.5 \mathrm{ppm}$.

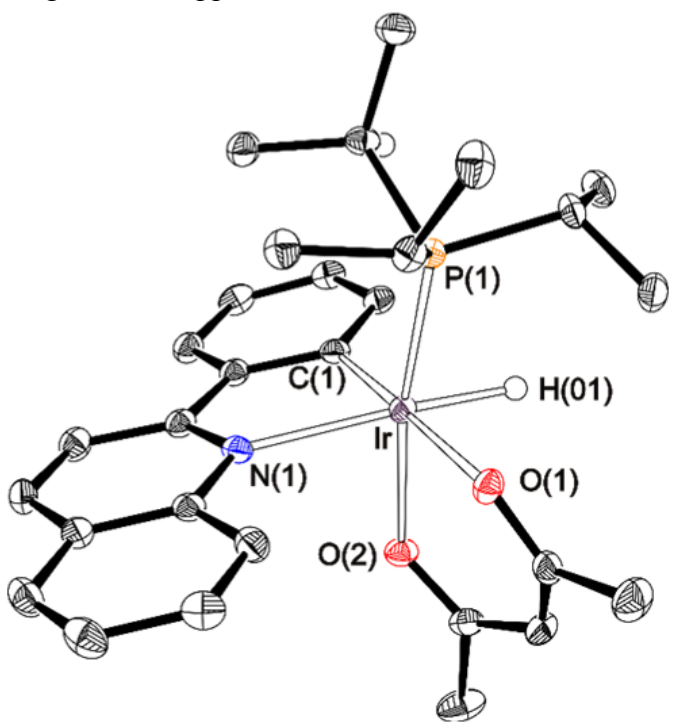

FIGURE 3. ORTEP diagram of complex 4 ( $50 \%$ probability ellipsoids). Hydrogen atoms (except the hydride) are omitted for clarity. Selected bond lengths $(\AA)$ and angles $(\operatorname{deg})$ : $\operatorname{Ir}-\mathrm{C}(1)=$ $1.990(3), \operatorname{Ir}-\mathrm{N}(1)=2.228(2), \operatorname{Ir}-\mathrm{P}(1)=2.2407(7), \operatorname{Ir}-\mathrm{O}(1)=$ 2.164(2), Ir-O(2) = 2.124(2), C(1)-Ir-N(1) = 78.85(10), H(01)-Ir$\mathrm{N}(1)=173.7(11), \mathrm{P}(1)-\mathrm{Ir}-\mathrm{O}(2)=170.94(5), \mathrm{O}(2)-\mathrm{Ir}-\mathrm{O}(1)=$ 86.68(8), $\mathrm{C}(1)-\mathrm{Ir}-\mathrm{O}(1)=176.17(10)^{\circ}$.

Alkenyl Complexes. The five-coordinate hydride cation $\mathbf{3}$ is the key to prepare alkenyl counterparts of $\mathbf{4}$ in two steps: alkyne insertion and subsequent acetylacetonate coordination (Scheme 2).

The unsaturated character of $\mathbf{3}$ certainly facilitates the insertion of the C-C triple bond of terminal alkynes into the Ir-H bond of the cation. Thus, the addition of 1.0 equiv of phenylacetylene to acetone solutions of $\mathbf{3}$, at room temperature, leads to the five-coordinate styryl derivative $\left[\operatorname{Ir}(E-\mathrm{CH}=\mathrm{CHPh})\left\{\kappa^{2}-\right.\right.$ $N, C$-(qui- $\left.\left.\left.\mathrm{C}_{6} \mathrm{H}_{4}\right)\right\}\left(\mathrm{P}^{i} \mathrm{Pr}_{3}\right)_{2}\right] \mathrm{BF}_{4}(\mathbf{5})$, after $1 \mathrm{~h}$, whereas the stirring of tetrahydrofuran solutions of 3 under $1 \mathrm{~atm}$ of acetylene, at room temperature, for $20 \mathrm{~min}$ affords the vinyl species $\left[\mathrm{Ir}\left(\mathrm{CH}=\mathrm{CH}_{2}\right)\left\{\kappa^{2}-N, C\right.\right.$ - $\left(\right.$ qui- $\left.\left.\left.\mathrm{C}_{6} \mathrm{H}_{4}\right)\right\}\left(\mathrm{P}^{i} \mathrm{Pr}_{3}\right)_{2}\right] \mathrm{BF}_{4} \quad$ (6), The salts were isolated as orange-red solids in high yield (96-66\%). The insertion of the hydrocarbons into the metal-hydride bond was confirmed by means of the X-ray structure of the styryl derivative 5. Figure 4 shows a view of the cation which is 
Scheme 2. Preparation of the Vinyl and Styryl Target Compounds

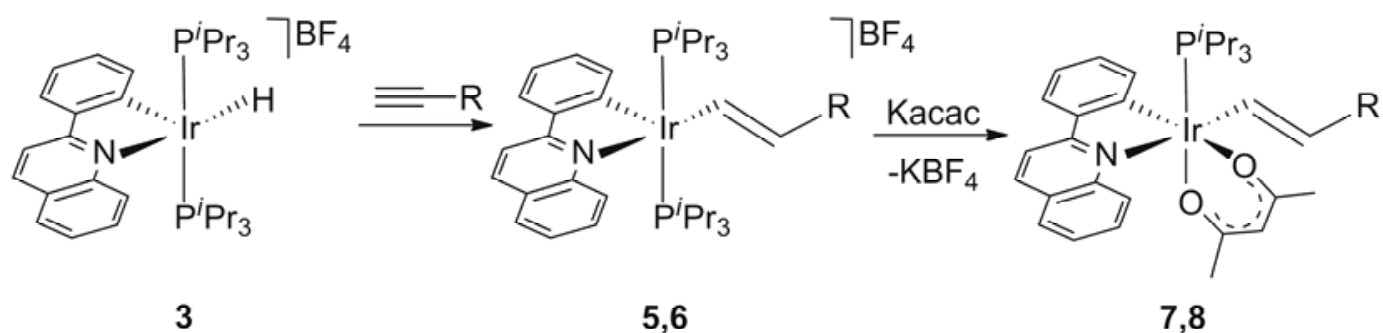

$\mathrm{R}=\mathrm{Ph}(\mathbf{5}$ and 7$), \mathrm{H}(\mathbf{6}$ and 8$)$

unsaturated as its precursor and also does not contain any $\pi$ donor ligand. The geometry around the metal center is as that of 3 with the styryl group at the position of the hydride ligand and $\mathrm{N}(1)-\operatorname{Ir}-\mathrm{C}(1)$ and $\mathrm{P}(1)-\mathrm{Ir}-\mathrm{P}(2)$ angles of $178.06(8)^{\circ}$ and $171.93(2)^{\circ}$, respectively. The most noticeable feature of the alkenyl ligand is the E-disposition of the metal fragment and the phenyl group at the $\mathrm{C}-\mathrm{C}$ double bond, which supports a cis-insertion. Ir-aryl and Ir-quinolyl bond lengths of 1.986(2) (Ir-C(9)) and 2.1542(19) (Ir-N(1)) A are statistically identical to those of $\mathbf{3}$, whereas the Ir-styryl distance of 2.035(2) $\AA$ compares well with the Ir-alkenyl distances previously reported for related compounds. ${ }^{24}$ The ${ }^{1} \mathrm{H},{ }^{13} \mathrm{C}\left\{{ }^{1} \mathrm{H}\right\}$ and ${ }^{31} \mathrm{P}\left\{{ }^{1} \mathrm{H}\right\}$ NMR spectra of $\mathbf{5}$ and $\mathbf{6}$, in dichloromethane- $d_{2}$, at room temperature are consistent with the structure shown in Figure 4. In agreement with the $E$-stereochemistry of the styryl ligand, the ${ }^{1} \mathrm{H}$ NMR spectrum of 5 shows at 9.78 and $6.73 \mathrm{ppm}$ the characteristic signals of the vinylic hydrogen atoms, with a $\mathrm{H}-\mathrm{H}$ coupling constant of $17.7 \mathrm{~Hz}$. For $\mathbf{6}$, the vinyl resonances are observed at 9.30, 6.13 and $5.41 \mathrm{ppm}$. In the ${ }^{13} \mathrm{C}\left\{{ }^{1} \mathrm{H}\right\} \mathrm{NMR}$ spectra the resonances due to the $\mathrm{C}_{\alpha}$ and $\mathrm{C}_{\beta}$ atoms of the alkenyl ligand appear at 134.8 and $133.6 \mathrm{ppm}$ for $\mathbf{5}$ and at 141.8 and $121.2 \mathrm{ppm}$ for $\mathbf{6}$, as triplets with C-P coupling constants of about 10 and $3 \mathrm{~Hz}$, respectively, whereas the

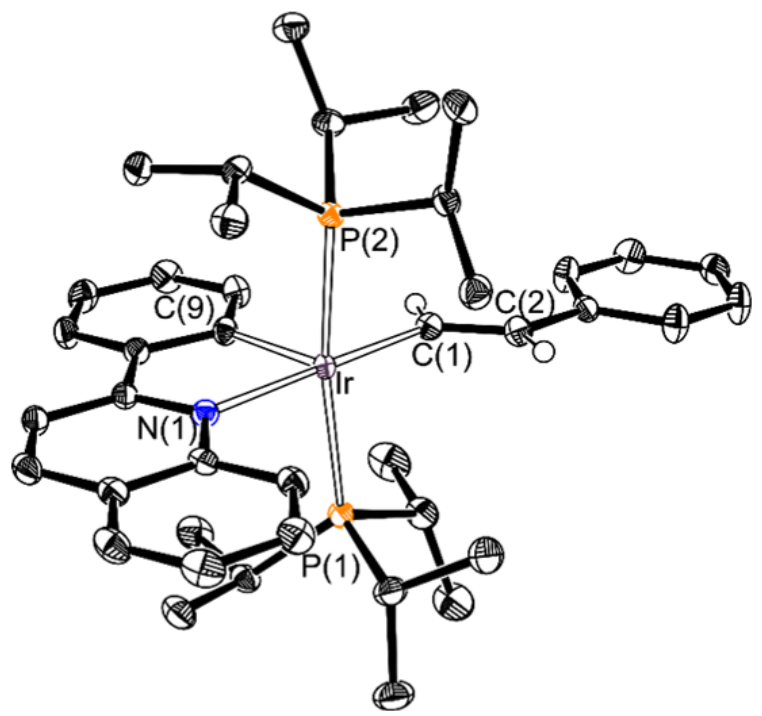

FIGURE 4. ORTEP diagram of the cation of complex $5(50 \%$ probability ellipsoids). Hydrogen atoms (except hydrogen substituents of the alkenyl) are omitted for clarity. Selected bond lengths $(\AA)$ and angles $(\mathrm{deg})$ : $\mathrm{Ir}-\mathrm{C}(1)=2.035(2), \operatorname{Ir}-\mathrm{C}(9)=1.985(2)$, Ir$\operatorname{Ir}-\mathrm{N}(1)=2.1542(19), \operatorname{Ir}-\mathrm{P}(1)=2.4255(6), \operatorname{Ir}-\mathrm{P}(2)=2.3776(6)$, $\mathrm{C}(1)-\operatorname{Ir}-\mathrm{N}(1)=178.06(8), \mathrm{P}(1)-\operatorname{Ir}-\mathrm{P}(2)=171.93(2)$. resonance corresponding to the metalated carbon atom of the phenyl group of the chelate is observed at about $119 \mathrm{ppm}$ for both salts as a triplet, with a C-P coupling constant of $6.4 \mathrm{~Hz}$. The ${ }^{31} \mathrm{P}\left\{{ }^{1} \mathrm{H}\right\}$ NMR spectra contain a singlet at $7.0 \mathrm{ppm}$ for $\mathbf{5}$ and at $6.5 \mathrm{ppm}$ for $\mathbf{6}$, as expected for equivalent phosphines.

Complexes 5 and $\mathbf{6}$ achieve the six-coordination number by reaction with $\mathrm{K}(\mathrm{acac})$, as their hydride precursor 3 . Treatment of tetrahydrofuran solutions of both five-coordinate alkenyl compounds with 1.0 equiv of $\mathrm{K}(\mathrm{acac})$ in methanol, at room temperature, for $12 \mathrm{~h}$ leads to the neutral six-coordinate alkenyl derivatives $\operatorname{Ir}(E-\mathrm{CH}=\mathrm{CHR})\left\{\kappa^{2}-N, C\right.$-(qui$\left.\left.\mathrm{C}_{6} \mathrm{H}_{4}\right)\right\}(\mathrm{acac})\left(\mathrm{P}^{i} \mathrm{Pr}_{3}\right)(\mathrm{R}=\mathrm{Ph}(7), \mathrm{H}(8))$, as a result of the chelate coordination of the acac ligand and the release of one of the phosphines. Complexes $\mathbf{7}$ and $\mathbf{8}$ were isolated as yellow solids in good yield (60-70\%). The styryl derivative 7 was characterized by X-ray diffraction analysis. Like in the hydride counterpart, the structure (Figure 5) suggests that the formation of $\mathbf{7}$ and $\mathbf{8}$ involves the initial coordination of one of the oxygen atoms of the incoming ligand at the free position of the pyramid of the starting compounds and the subsequent displacement of a phosphine by the remaining oxygen atom. Thus, the resulting octahedron keeps the alkenyl ligand trans

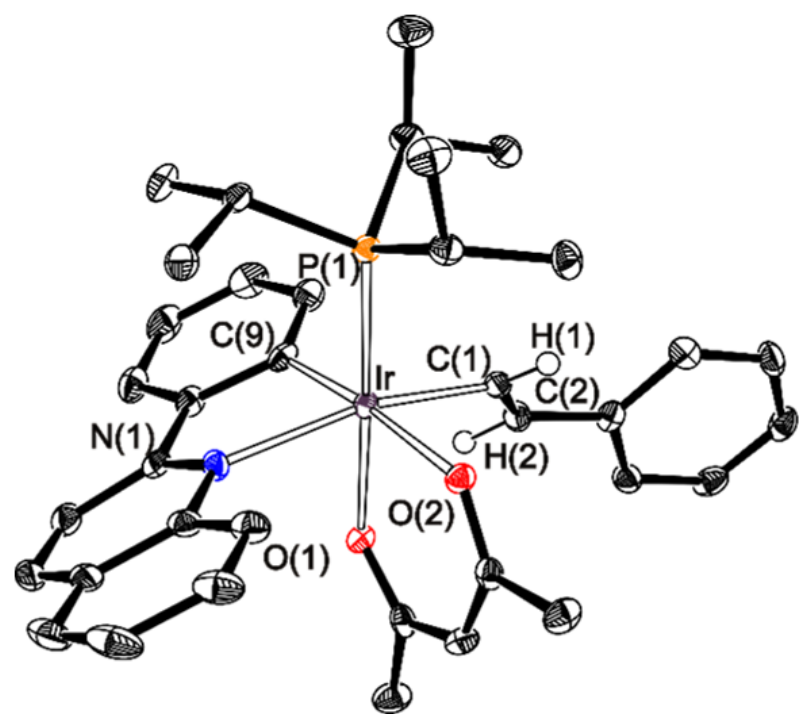

FIGURE 5. ORTEP diagram of complex 7 (50\% probability ellipsoids). Hydrogen atoms (except hydrogen substituents of the alkenyl) are omitted for clarity. Selected bond lengths $(\AA)$ and angles $(\mathrm{deg})$ : $\mathrm{Ir}-\mathrm{C}(1)=2.020(3), \operatorname{Ir}-\mathrm{C}(9)=2.000(3), \operatorname{Ir}-\mathrm{N}(1)=$ $2.199(2), \operatorname{Ir}-\mathrm{P}(1)=2.2844(8), \mathrm{C}(1)-\mathrm{Ir}-\mathrm{N}(1)=164.01(10), \mathrm{O}(1)-\mathrm{Ir}-$ $\mathrm{P}(1)=177.80(6), \mathrm{O}(2)-\mathrm{Ir}-\mathrm{C}(9)=173.36(9)$. 


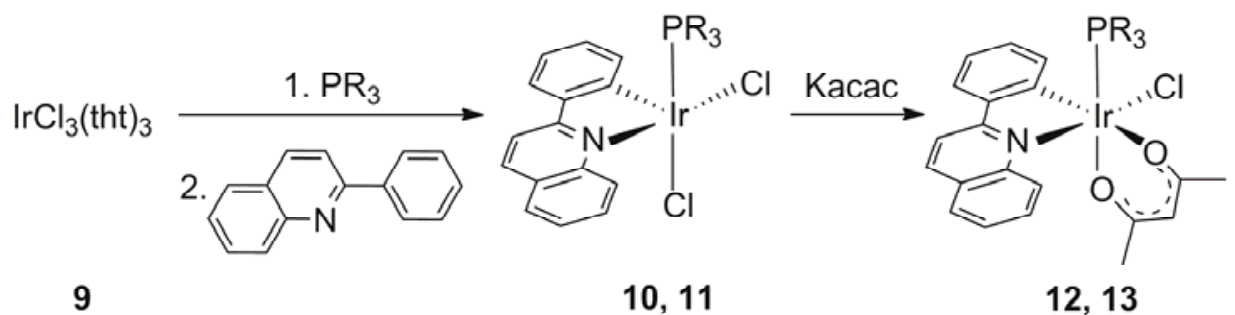

$\mathrm{R}={ }^{i} \operatorname{Pr}(10,12), \mathrm{Ph}(11,13)$

disposed to the nitrogen atom of the $\mathrm{N}, \mathrm{C}$-chelate group $\mathrm{C}(1)$ $\left.\operatorname{Ir}-\mathrm{N}(1)=164.01(10)^{\circ}\right)$. At the perpendicular plane, the oxygen atoms $\mathrm{O}(1)$ and $\mathrm{O}(2)$ of acac lie trans to the phosphine and phenyl group, with $\mathrm{O}(1)-\mathrm{Ir}-\mathrm{P}(1)$ and $\mathrm{O}(2)-\mathrm{Ir}-\mathrm{C}(9)$ angles of $177.80(6)^{\circ}$ and $173.36(9)^{\circ}$, respectively. The $\operatorname{Ir}-\mathrm{C}(1), \operatorname{Ir}-\mathrm{C}(9)$, and $\operatorname{Ir}-\mathrm{N}(1)$ bond lengths of 2.020(3), 2.000(3), and 2.199(2) $\AA$, respectively, compare well with those of 5. The ${ }^{1} \mathrm{H},{ }^{13} \mathrm{C}\left\{{ }^{1} \mathrm{H}\right\}$ and ${ }^{31} \mathrm{P}\left\{{ }^{1} \mathrm{H}\right\}$ NMR spectra of $\mathbf{7}$ and $\mathbf{8}$, in dichloromethane- $d_{2}$, at room temperature are consistent with the structure shown in Figure 5. In the ${ }^{1} \mathrm{H}$ NMR spectrum, the resonances corresponding to the vinylic hydrogen atoms of the alkenyl ligand appear at 9.9 and $4.90 \mathrm{ppm}$ for 7 and at $8.39,5.47$, and $4.91 \mathrm{ppm}$ for 8 , whereas the $C_{\alpha}$ and $C_{\beta}$ signals of this ligand in the ${ }^{13} \mathrm{C}\left\{{ }^{1} \mathrm{H}\right\}$ NMR spectra are observed at 132.2 and $132.1 \mathrm{ppm}$ for 7 and at 136.4 and $116.3 \mathrm{ppm}$ for $\mathbf{8}$. The resonance corresponding to the metalated phenyl carbon atom appears at about $148 \mathrm{ppm}$ for both compounds. A singlet at $9 \mathrm{ppm}$ in the ${ }^{31} \mathrm{P}\left\{{ }^{1} \mathrm{H}\right\}$ NMR spectra is also a characteristic feature of these compounds.

Chloride complexes. Pentahydride 1 is not a useful starting material to prepare a chloride target compound related to 4,7 and $\mathbf{8}$. So, we decided to use the tetrahydrothiophene deriva tive $\mathrm{IrCl}_{3}(\text { tht })_{3}(9)$, which had previously proven to be effective for the preparation of OLED phosphors, through phosphine coordination and chelate-supported $\mathrm{C}-\mathrm{H}$ bond activation reactions. ${ }^{25}$ Scheme 3 summarizes the procedure used in this case.

The chloride-target compound was prepared via the fivecoordinate cis-dichloride intermediate $\operatorname{IrCl}_{2}\left\{\kappa^{2}-N, C\right.$-(qui$\left.\left.\mathrm{C}_{6} \mathrm{H}_{4}\right)\right\}\left(\mathrm{P}^{i} \mathrm{Pr}_{3}\right)(\mathbf{1 0})$, which was obtained as and orange solid in $58 \%$ yield, in one-pot synthesis procedure, in refluxing decalin, by sequential addition of 1.0 equiv of triisopropylphosphine and 1.0 equiv of 2-phenylquinoline to 9 . Under the same conditions, using triphenylphosphine instead of triisopropylphosphine, the triphenylphosphine counterpart $\mathrm{IrCl}_{2}\left\{\kappa^{2}-N, C\right.$-(qui- $\left.\left.\mathrm{C}_{6} \mathrm{H}_{4}\right)\right\}\left(\mathrm{PPh}_{3}\right)(\mathbf{1 1})$ was also isolated as an orange solid in good yield, $78 \%$. The unsaturated character of these intermediates was confirmed by means of the X-ray diffraction structure of $\mathbf{1 0}$ (Figure 6). Like for the previous five-coordinate species of this work, the geometry around the iridium atom can be rationalized as a distorted square pyramid with the metalated carbon atom of the N,C-chelate group in the apex. At the base the chloride ligands $\mathrm{Cl}(1)$ and $\mathrm{Cl}(2)$ lie trans to the phosphine and the nitrogen atom of the quinolyl group with $\mathrm{Cl}(1)-\mathrm{Ir}-\mathrm{P}(1)$ and $\mathrm{Cl}(2)-\mathrm{Ir}-\mathrm{N}(1)$ angles of $174.63(3)^{\circ}$ and $170.49(7)^{\circ}$, respectively. In this case, the four atoms forming the base are also approximately in a plane, whereas the metal center is located 0.1750(12) $\AA$ above this plane towards the apical position. The iridium-chelate $\mathrm{Ir}-\mathrm{C}(1)$ and Ir-N(2) distances of 1.978(3) and 2.040(2) A, respectively, compare well with those observed in the previous structures.
The ${ }^{13} \mathrm{C}\left\{{ }^{1} \mathrm{H}\right\}$ NMR spectra of $\mathbf{1 0}$ and $\mathbf{1 1}$, in dichloromethane$d_{2}$, at room temperature show the resonance due to the metalated carbon of the phenyl group at $126.0 \mathrm{ppm}$ for $\mathbf{1 0}$ and $124.0 \mathrm{ppm}$ for 11, in agreement with the chemical shifts observed for the five-coordinate complexes $\mathbf{3}, \mathbf{5}$, and $\mathbf{6}$. The ${ }^{31} \mathrm{P}\left\{{ }^{1} \mathrm{H}\right\}$ NMR spectra contain a singlet at $-2.5 \mathrm{ppm}$ for $\mathbf{1 0}$ and at $-11.09 \mathrm{ppm}$ for $\mathbf{1 1}$.

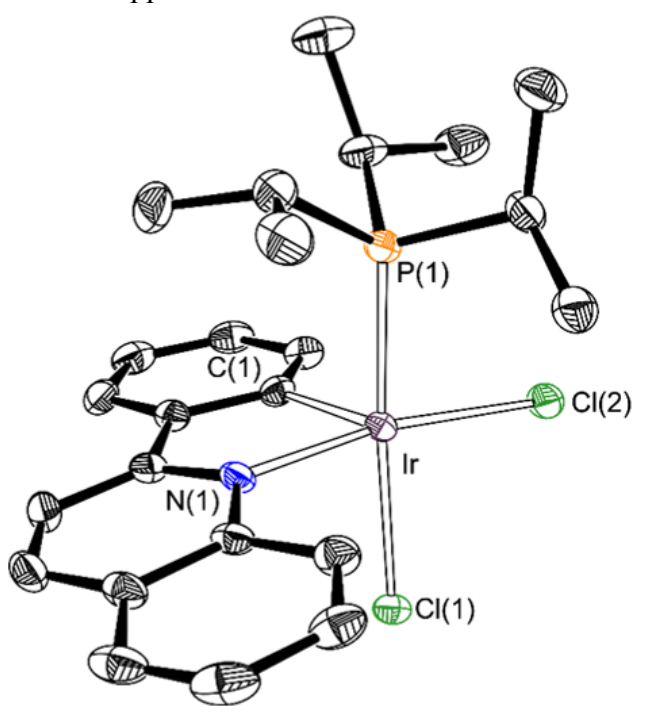

FIGURE 6. ORTEP diagram of complex $10(50 \%$ probability ellipsoids). Hydrogen atoms are omitted for clarity. Selected bond lengths $(\AA)$ and angles $(\mathrm{deg})$ : $\operatorname{Ir}-\mathrm{C}(1)=1.978(3), \operatorname{Ir}-\mathrm{N}(1)=$ $2.040(2), \operatorname{Ir}-\mathrm{P}(1)=2.2976(8), \operatorname{Ir}-\mathrm{Cl}(1)=2.3844(7), \operatorname{Ir}-\mathrm{Cl}(2)=$ $2.3478(8), \mathrm{Cl}(2)-\mathrm{Ir}-\mathrm{N}(1)=170.49(7), \mathrm{Cl}(1)-\mathrm{Ir}-\mathrm{P}(1)=174.63(3)$.

Complexes 10 and $\mathbf{1 1}$ react with $\mathrm{K}$ (acac), under the same conditions as $\mathbf{3}, \mathbf{5}$ and $\mathbf{6}$, to afford the six-coordinate compounds $\mathrm{IrCl}\left\{\kappa^{2}-N, C\right.$-(qui- $\left.\left.\mathrm{C}_{6} \mathrm{H}_{4}\right)\right\}($ acac $)\left(\mathrm{PR}_{3}\right)\left(\mathrm{PR}_{3}=\mathrm{P}^{i} \mathrm{Pr}_{3}(\mathbf{1 2})\right.$, $\left.\mathrm{PPh}_{3}(\mathbf{1 3})\right)$, which were isolated as orange (12) and yellow (13) solids in moderated yields $(40-60 \%)$. The X-ray diffraction structure of 12 (Figure 7) confirms that the stereochemistry of these compounds is as that of the hydride and alkenyl counterparts 4,7 and $\mathbf{8}$, with the chloride ligand trans disposed to the nitrogen atom of the quinolyl group $(\mathrm{Cl}(1)-\operatorname{Ir}-\mathrm{N}(1))=$ $\left.170.81(8)^{\circ}\right)$. At the perpendicular plane, the oxygen atoms $\mathrm{O}(1)$ and $\mathrm{O}(2)$ of acac lie trans to the phosphine and phenyl group with $\mathrm{O}(1)-\mathrm{Ir}-\mathrm{P}(1)$ and $\mathrm{O}(2)-\mathrm{Ir}-\mathrm{C}(1)$ angles of $177.12(8)^{\circ}$ and $170.87(12)^{\circ}$, respectively. The $\operatorname{Ir}-\mathrm{C}(1)$ and $\operatorname{Ir}-\mathrm{N}(1)$ distances of 1.998(3) and 2.091(3) $\AA$ compare well with those of 4, 7 and 8. In the ${ }^{13} \mathrm{C}\left\{{ }^{1} \mathrm{H}\right\}$ NMR spectra of 12 and 13 , in dichloromethane- $d_{2}$, at room temperature, the resonance corresponding to the metalated carbon 
Table 1. Selected UV/vis Experimental Data, Computed TD-DFT THF Vertical Excitation Energies and their Composition.

\begin{tabular}{|c|c|c|c|c|c|c|}
\hline Complex & $\lambda \mathbf{n m}($ expt) & $\varepsilon 10^{3} \mathrm{M}^{-1} \mathrm{~cm}^{-1}$ & excitation energy, $\mathrm{nm}$ & $\begin{array}{l}\text { oscillator } \\
\text { strength }\end{array}$ & transition & $\begin{array}{c}\text { Contribution } \\
\%\end{array}$ \\
\hline \multirow[t]{4}{*}{4} & 266 & 23.32 & 267 & 0.109 & $\mathrm{HOMO}-3 \rightarrow \mathrm{LUMO}+1$ & 60 \\
\hline & 330 & 9.97 & 326 & 0.1088 & HOMO-3 $\rightarrow$ LUMO & 80 \\
\hline & 440 & 2.852 & 442 & 0.0571 & $\mathrm{HOMO} \rightarrow \mathrm{LUMO}$ & 97 \\
\hline & 530 & 0.62 & & & & \\
\hline \multirow[t]{7}{*}{7} & 298 & 27.48 & 300 & 0.1279 & HOMO-7 $\rightarrow$ LUMO & 26 \\
\hline & & & & & $\mathrm{HOMO} \rightarrow \mathrm{LUMO}+5$ & 15 \\
\hline & 320 & 19.9 & 320 & 0.1023 & HOMO-4 $\rightarrow$ LUMO & 44 \\
\hline & & & & & HOMO- $1 \rightarrow$ LUMO+2 & 35 \\
\hline & 408 & 5.00 & 430 & 0.0715 & HOMO- $1 \rightarrow$ LUMO & 97 \\
\hline & 486 & 1.10 & 487 & 0.0384 & $\mathrm{HOMO} \rightarrow$ LUMO & 97 \\
\hline & 510 & 0.58 & & & & \\
\hline \multirow[t]{5}{*}{8} & 266 & 23.4 & 260 & 0.1616 & $\mathrm{HOMO}-4 \rightarrow \mathrm{LUMO}+2$ & 48 \\
\hline & 310 & 11.9 & 320 & 0.1891 & HOMO-4 $\rightarrow$ LUMO & 52 \\
\hline & 380 & 3.75 & 380 & 0.0438 & HOMO-2 $\rightarrow$ LUMO & 89 \\
\hline & 440 & 2.60 & 450 & 0.0072 & $\mathrm{HOMO} \rightarrow \mathrm{LUMO}$ & 94 \\
\hline & 512 & 0.40 & & & & \\
\hline \multirow[t]{6}{*}{12} & 282 & 26.45 & 291 & 0.1021 & $\mathrm{HOMO}-2 \rightarrow \mathrm{LUMO}+1$ & 55 \\
\hline & 326 & 13.95 & 330 & 0.0832 & HOMO-4 $\rightarrow$ LUMO & 52 \\
\hline & & & & & $\mathrm{HOMO} \rightarrow \mathrm{LUMO}+1$ & 32 \\
\hline & 376 & 5.70 & 388 & 0.0569 & HOMO-2 $\rightarrow$ LUMO & 89 \\
\hline & 440 & 3.20 & 443 & 0.0129 & $\mathrm{HOMO} \rightarrow \mathrm{LUMO}$ & 98 \\
\hline & 486 & 0.825 & & & & \\
\hline \multirow[t]{7}{*}{13} & 262 & 28.28 & 238 & 0.0576 & $\mathrm{HOMO}-3 \rightarrow \mathrm{LUMO}+3$ & 33 \\
\hline & & & & & $\mathrm{HOMO}-4 \rightarrow \mathrm{LUMO}+1$ & 19 \\
\hline & 315 & 14.50 & 309 & 0.0681 & HOMO-7 $\rightarrow$ LUMO & 23 \\
\hline & & & & & $\mathrm{HOMO} \rightarrow \mathrm{LUMO}+1$ & 21 \\
\hline & 410 & 4.35 & 405 & 0.0551 & HOMO-1 $\rightarrow$ LUMO & 92 \\
\hline & 440 & 3.2 & 424 & 0.0131 & $\mathrm{HOMO} \rightarrow$ LUMO & 96 \\
\hline & 480 & 1.158 & & & & \\
\hline
\end{tabular}

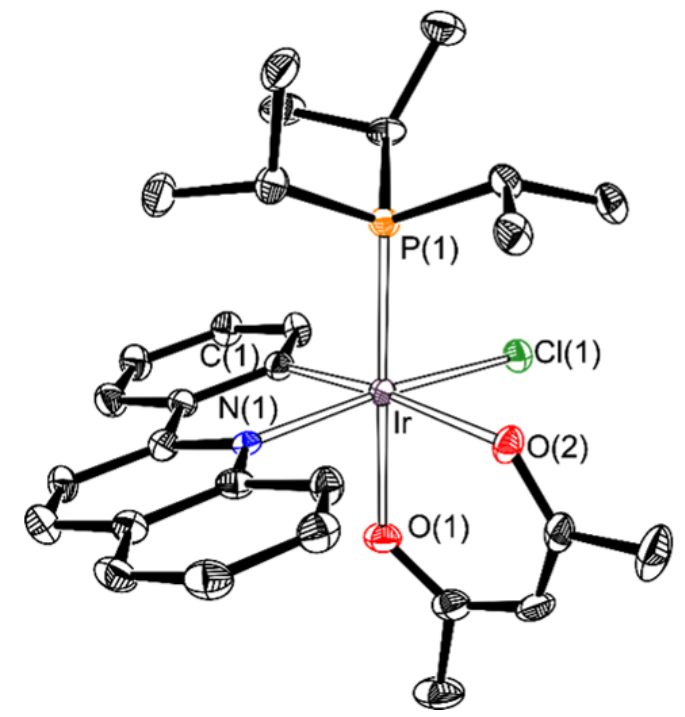

FIGURE 7. ORTEP diagram of complex 12 (50\% probability ellipsoids). Hydrogen atoms are omitted for clarity. Selected bond lengths $(\AA)$ and angles $(\mathrm{deg})$ : $\operatorname{Ir}-\mathrm{C}(1)=1.998(3), \operatorname{Ir}-\mathrm{N}(1)$ $=2.091(3), \operatorname{Ir}-\mathrm{P}(1)=2.2893(9), \mathrm{Ir}-\mathrm{O}(1)=2.096(2), \mathrm{Ir}-\mathrm{O}(2)=$ 2.144(2), $\operatorname{Ir}-\mathrm{Cl}(1)=2.3559(8), \mathrm{C}(1)-\operatorname{Ir}-\mathrm{N}(1)=80.41(12)$, $\mathrm{Cl}(1)-\mathrm{Ir}-\mathrm{N}(1)=170.81(8),\left(\mathrm{O}(1)-\mathrm{Ir}-\mathrm{P}(1)=177.12(8)^{\circ}, \mathrm{O}(2)\right.$-Ir$\mathrm{C}(1)=170.87(12)$. atom of the phenyl group appears at $146.0 \mathrm{ppm}$ for $\mathbf{1 2}$ and at $144.2 \mathrm{ppm}$ for 13. The ${ }^{31} \mathrm{P}\left\{{ }^{1} \mathrm{H}\right\}$ NMR spectra contain a singlet at $-16.3 \mathrm{ppm}$ for $\mathbf{1 2}$ and at $-28.0 \mathrm{ppm}$ for $\mathbf{1 3}$.

Photophysical Properties of the Target Complexes. UV/vis absorption spectra of $4.0 \cdot 10^{-5} \mathrm{M} 2$-methyltetrahydrofuran solutions of the six-coordinate complexes $4,7,8,12$ and 13 , at room temperature, are collected in Table 1 . The spectra of the five compounds are similar (Figures S34-S38), showing three different zones: $240-360 \mathrm{~nm}, 380-480 \mathrm{~nm}$ and $>480 \mathrm{~nm}$. Time dependence DFT calculations (B3LYP-GD3//SDD(f)/6$31 \mathrm{G}^{* *}$, computed in tetrahydrofuran as solvent) indicate that the absorptions of highest energy correspond to ligand centered (LC) transitions mainly involving the N,C-chelate group. The spectra in the region of moderate absorption bands between 380 and $480 \mathrm{~nm}$ show some dependence of the $1 \mathrm{~m}$ ' ligand, which seems to determine the contribution of the metal center to the HOMO of the complexes, decreasing in the sequence $\mathrm{H}>\mathrm{CH}=\mathrm{CH}_{2}>\mathrm{Cl}>\mathrm{CH}=\mathrm{CHPh}$ (Tables $\mathrm{S} 11-\mathrm{S} 15$. The frontier orbitals of the complexes are shown in Figures S39$\mathrm{S} 43)$. The spectrum of the hydride complex 4 shows a absorption at $440 \mathrm{~nm}$, corresponding to a HOMO $(44 \% \mathrm{Ir}+46 \%$ $\mathrm{N}, \mathrm{C}) \rightarrow$ LUMO $(97 \% \mathrm{~N}, \mathrm{C})$ transition. In contrast to $\mathbf{4}$, the spectrum of the styryl complex 7 contains two bands at 408 and $440 \mathrm{~nm}$. The first of them corresponds to a transition similar to the above mentioned, HOMO-1 (41\% Ir $+51 \%$ $\mathrm{N}, \mathrm{C}) \rightarrow$ LUMO $(96 \% \mathrm{~N}, \mathrm{C})$, whereas the second one mainly 
Table 2. Photophysical Properties of Complexes 4, 7, 8, 12 and 13 and theoretical computed emissions.

\begin{tabular}{|c|c|c|c|c|c|c|}
\hline Complex & Calculated emission (nm) & media $(T / K)$ & $\lambda_{\mathrm{em}}(\mathrm{nm})$ & $\lambda_{\text {exc }}(\mathrm{nm})$ & $\tau(\mu \mathrm{s})$ & $\Phi^{\mathrm{a}}$ \\
\hline \multirow[t]{3}{*}{4} & 551 & solid (298) & 575 & 400 & 1.2 & 0.75 \\
\hline & & 2-MeTHF (298) & 562 & 400 & 0.6 & \\
\hline & & 2-MeTHF (77) & 525,564 & 370 & 6.6 & \\
\hline \multirow[t]{3}{*}{7} & 583 & solid (298) & 581 & 400 & 1.4 & 0.04 \\
\hline & & 2-MeTHF (298) & 592 & 400 & 0.6 & \\
\hline & & 2-MeTHF (77) & 535,570 & 400 & 5.7 & \\
\hline \multirow[t]{3}{*}{8} & 553 & solid (298) & 570,606 & 410 & 1.9 & 0.64 \\
\hline & & 2-MeTHF (298) & 577 & 400 & 0.8 & \\
\hline & & 2-MeTHF (77) & 526,564 & 380 & 4.0 & \\
\hline \multirow[t]{3}{*}{12} & 570 & solid (298) & 613 & 430 & 1.2 & 0.27 \\
\hline & & 2-MeTHF (298) & 605 & 450 & 1.4 & \\
\hline & & 2-MeTHF (77) & 551,591 & 470 & 3.1 & \\
\hline \multirow[t]{3}{*}{13} & 568 & solid (298) & 565 & 400 & 1.8 & 0.28 \\
\hline & & 2-MeTHF (298) & 584 & 400 & 2.8 & \\
\hline & & 2-MeTHF (77) & 536,573 & 420 & 6.0 & \\
\hline
\end{tabular}

${ }^{a}$ Measurements in solid state by doping 5\% sample in PMMA film.

implies to the styryl ligand and the N,C-chelate group with a small contribution of the metal, HOMO (23\% $\mathrm{Ir}+70 \%$ $\mathrm{CH}=\mathrm{CHPh}) \rightarrow$ LUMO $(96 \% \mathrm{~N}, \mathrm{C})$. The spectrum of the vinyl derivative 8 has also two bands in this region, at 380 and 440 $\mathrm{nm}$. The higher energy band is due to a HOMO- $\rightarrow$ LUMO transition, being the HOMO-2 mainly centered on the metal $(39 \%)$ and the acac $(32 \%)$ ligand with some contribution of the vinyl group (16\%), whereas the LUMO is centered on the $\mathrm{N}, \mathrm{C}$-chelate ligand (97\%). The band of lower energy corresponds to a HOMO $\rightarrow$ LUMO transition. Like in 7 the HOMO is centered on the metal and the alkenyl group but, in this case, the contributions are conversely, $44 \%$ on Ir and $36 \%$ on $\mathrm{CH}=\mathrm{CH}_{2}$. The spectrum of the chloride complex 12 also contains two moderate absorption bands at 376 and $440 \mathrm{~nm}$ due to HOMO- $\rightarrow$ LUMO and HOMO $\rightarrow$ LUMO transitions. HOMO2 is centered on the metal center $(40 \%)$ and the chloride ligand $(40 \%)$, whereas the HOMO is centered on the metal center $(38 \%)$ and the acac ligand $(37 \%)$ and has further a significant contribution of the chloride anion $(16 \%)$. Like in the previous cases, the LUMO is centered on the N,C-chelate ligand (96\%). The replacement of triisopropylphosphine by triphenylphosphine does not produce significant changes in the appearance of this region of the spectrum, although it increases the role of the $\mathrm{N}, \mathrm{C}$-chelate group in the transitions while diminishes that of the chloride ligand. The weak absorption tails after $480 \mathrm{~nm}$ are usually assigned to theoretically forbidden ${ }^{3}$ MLCT transitions, caused by the large spin orbit coupling constant introduced by the iridium center. ${ }^{26}$

Complexes 4, 7, 8, 12 and 13 are yellow-orange emissive upon photoexcitation in the solid state at room temperature and in 2methyltetrahydrofuran at room temperature and at $77 \mathrm{~K}$, displaying bands centered between 613 and $525 \mathrm{~nm}$. Figure 8 depits the emission spectra, whereas Table 2 collects experimental and calculated wavelengths, lifetimes and quantumyields. The emissions can be attributed to $T_{1}$ excited states originated by $\mathrm{HOMO} \rightarrow$ LUMO charge transfer transitions for 4, 7, 12 and 13 and by HOMO- $\rightarrow$ LUMO for 8 . Figure 9 displays the spin density distribution calculated for the $T_{1}$ states at their minimum energy geometry. In accordance with this, good agreement is observed between the experimental wavelengths and those calculated estimating the difference in energy between the optimized triplet state and the singlet state. The lifetimes lie in the range 6.6-0.6 $\mu \mathrm{s}$, whereas
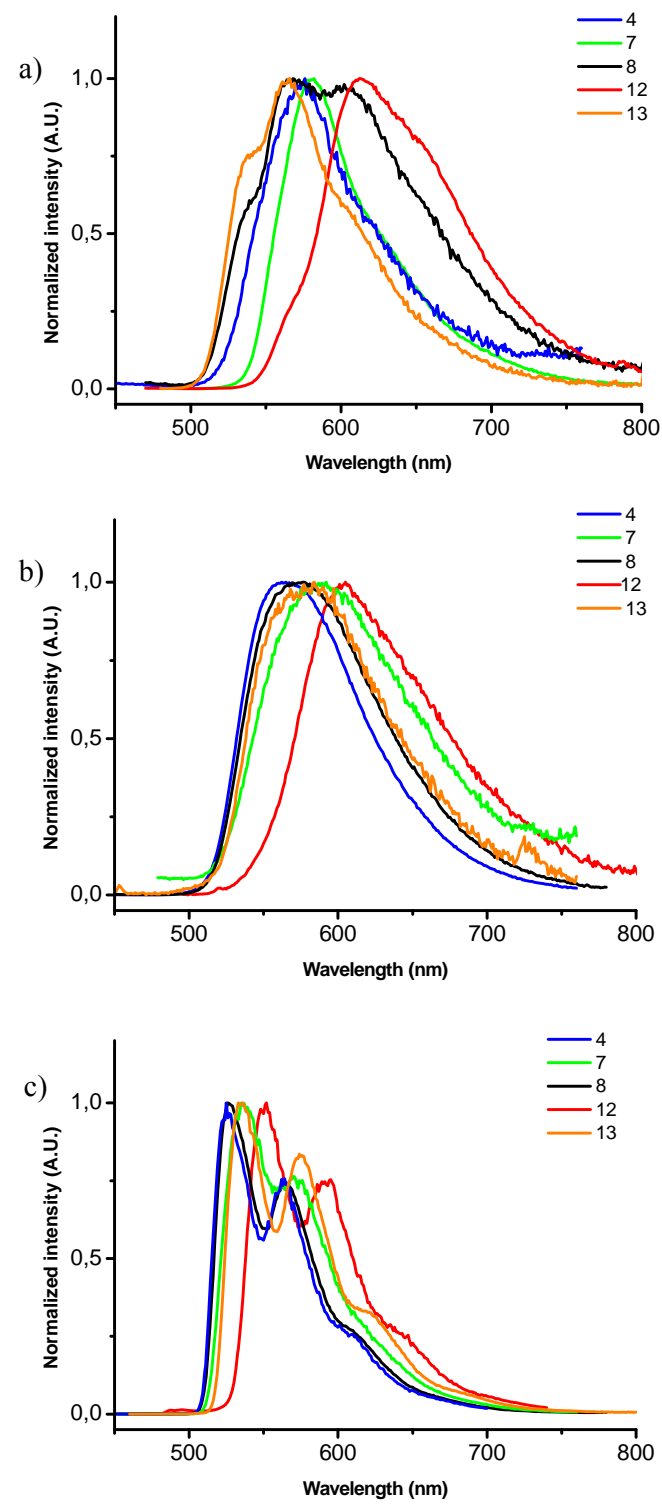

Figure 8. Emission spectra in the solid state at $298 \mathrm{~K}$ (a), 2MeTHF at 298 (b) and in 2-MeTHF at $77 \mathrm{~K}$ (c) for complexes $4,7,8,12$ and 13 . 
the quantum yields, measurement in solid state by doping $5 \%$ sample in PMMA film, are between 0.75 and 0.04 .

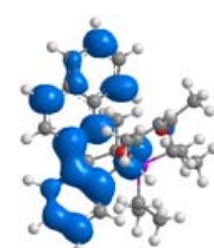

a)

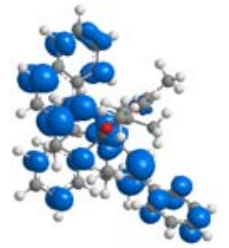

b)

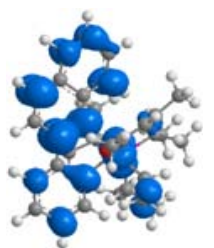

c)

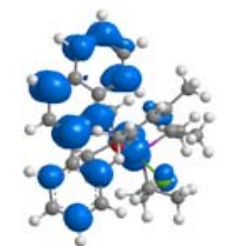

d)

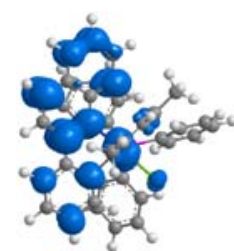

e)

Figure 9. Unpaired electron spin-density contours (0.03 au) calculated for the $\mathrm{T}_{1}$ state of $4(\mathrm{a}), \mathbf{7}(\mathrm{b}), \mathbf{8}(\mathrm{c}), \mathbf{1 2}(\mathrm{d})$ and $\mathbf{1 3}(\mathrm{e})$.

The comparison of data collected in Table 2 and the spectra of Figure 8 reveals three noticeable features of these compounds: (i) The $1 \mathrm{~m}$ ' ligand has a poor influence on the color, displaying the emission a slight shift from yellow to orange in the sequence $\mathrm{H}<\mathrm{CH}=\mathrm{CH}_{2}<\mathrm{CH}=\mathrm{CHPh}<\mathrm{Cl}$. (ii) In methyltetrahydrofuran, at $77 \mathrm{~K}$, the life times slightly increase and the emissions are splitted into two bands, which is consistent with the notable contribution of the ligands to the HOMO of the complexes. And (iii) in contrast to the color, the quantum yields show some dependency upon the $1 \mathrm{~m}$ ' ligand, increasing in the sequence $\mathrm{CH}=\mathrm{CHPh}<\mathrm{Cl}<\mathrm{CH}=\mathrm{CH}_{2}<\mathrm{H}$.

The accessibility of the ${ }^{3} \mathrm{MC}$ calculated excited states decreases in the sequence $\mathrm{H}<\mathrm{CH}=\mathrm{CHPh} \approx \mathrm{CH}=\mathrm{CH}_{2}<\mathrm{Cl}$ (Figure S64), in agreement with the field strength of the $1 \mathrm{~m}$ ' ligands. These results are consistent with the decrease of the quantum yield in the sequence $\mathbf{4}>\mathbf{8}>\mathbf{1 2}$, which suggest that, for these complexes, thermally accessible ${ }^{3} \mathrm{MC}$ states can play some role in non-radiative decay pathways. However, the exceptional low quantum yield of 7 appears to be due their very small radiative emission rate (Table S16) as a consequence of a higher LLCT contribution to the singlet-triplet transition. ${ }^{27}$

\section{CONCLUDING REMARKS}

This study reveals the synthetic procedures for the selective preparation of a novel family of phosphorescent heteroleptic iridium(III) emitters and their photophysical properties. The new compounds are of the type $\left[3 \mathrm{~b}+3 \mathrm{~b}^{\prime}+2 \mathrm{~m}+1 \mathrm{~m}\right.$ '] and have the general formula IrX $\left\{\kappa^{2}-N, C\right.$ - $\left(\right.$ qui- $\left.\left.\mathrm{C}_{6} \mathrm{H}_{4}\right)\right\}(\mathrm{acac})\left(\mathrm{P}^{i} \mathrm{Pr}_{3}\right)(\mathrm{X}=$ $\mathrm{H}, \mathrm{PCH}=\mathrm{CH}_{2}, \mathrm{CH}_{2}=\mathrm{CH}, \mathrm{Cl}$ ). Their X-ray diffraction structures show that the stereochemistry around the iridium(III) center can be in all the cases rationalized as an octahedron with the $1 \mathrm{~m}$ ' ligand (X) disposed trans to the nitrogen atom of the N,C-chelate. At the perpendicular plane the oxygen atoms of the acac lie trans to the phenyl group and phosphine.

The preparation of these compounds uses typical organometallic reactions such as the chelate-supported $\mathrm{C}-\mathrm{H}$ bond activation and alkyne insertion, in the case of the alkenyl complexes, and takes place via five-coordinate intermediates, which coordinate acac and release a monodentate ligand. The starting complexes depend upon the $1 \mathrm{~m}$ ' ligand. While the $\mathrm{d}^{4}-$ pentahydride $\operatorname{IrH}_{5}\left(\mathrm{P}^{i} \mathrm{Pr}_{3}\right)_{2}$ is used to obtain the hydride and alkenyl compounds, the solvento complex $\mathrm{IrCl}_{3}(\text { tht })_{3}$ is employed to form the chloride counterpart.

These six-coordinate complexes are yellow-orange emissive upon photoexcitation with short life times and quantum yields in the range $0.04-0.75$. The $1 \mathrm{~m}$ ' ligand, that characterizing the complex, has a poor influence on the emission color. However, it determines the quantum yield, which increases in the sequence $\mathrm{CH}=\mathrm{CHPh}<\mathrm{Cl}<\mathrm{CH}=\mathrm{CH}_{2}<\mathrm{H}$, as the contribution of the metal center to the HOMO of the complexes also increases.

In conclusion, rational synthetic procedures for the selective preparation of a determined stereoisomer of phosphorescent heteroleptic iridium(III) complexes of the type $\left[3 b+3 b^{\prime}+2 m+1 m^{\prime}\right]$ are reported and the influence of the $1 m$ ' ligand on the emission color and the quantum yield is analyzed.

\section{EXPERIMENTAL SECTION}

General Information. All the solvents were collected oxygen- and water-free from an MBraun solvent purification apparatus with the exception of decaline which was dried and distilled under argon. Pentane-2,4-dione was distilled urder vacuum. All the reactions have been run in rigorous exclusion of air using Schlenk-tube techniques. ${ }^{1} \mathrm{H},{ }^{31} \mathrm{P}\left\{{ }^{1} \mathrm{H}\right\}$, and ${ }^{13} \mathrm{C}\left\{{ }^{1} \mathrm{H}\right\}$ NMR spectra were recorded on Bruker 300 ARX, Bruker Avance $300 \mathrm{MHz}$, and Bruker Avance $400 \mathrm{MHz}$ instruments. The ${ }^{19} \mathrm{~F}$ NMR spectra were recorded in a $300 \mathrm{MHz}$ Varian Gemini apparatus. The Chemical shifts are expressed in parts per million and the residual solvent peaks $\left({ }^{1} \mathrm{H},{ }^{13} \mathrm{C}\left\{{ }^{1} \mathrm{H}\right\}\right)$ or external $85 \%$ $\mathrm{H}_{3} \mathrm{PO}_{4}\left({ }^{31} \mathrm{P}\left\{{ }^{1} \mathrm{H}\right\}\right)$, or external $\mathrm{CFCl}_{3}\left({ }^{19} \mathrm{~F}\right)$ have been used as reference. Coupling constants $J$ and $N$ are given in hertz. Attenuated total reflection infrared spectra (ATR-IR) experiments were carried out with solid samples on a Perkin-Elmer Spectrum 100 FT-IR spectrometer. $\mathrm{C}, \mathrm{H}$, and $\mathrm{N}$ analyses were carried out in a Perkin-Elmer 2400 $\mathrm{CHNS} / \mathrm{O}$ analyzer. High-resolution electrospray mass spectra were acquired using a MicroTOF-Q hybrid quadrupole time-of-flight spectrometer (Bruker Daltonics, Bremen, Germany). The UV-vis spectra were recorded in a Thermo Scientific Evolution 600 UVVisible spectrophorometer. The steady-state photoluminicesce spectra were carried out in a Horiba Jovin Yvon Fluorolog-3-11 Tau-3 spectrophotometer. The lifetimes were measured with a Datastation HUBB with a nanoLED controller and the DAS6 software. The Quantum yields were measured with a Quantum Yield HAMAMATSU Absolute PL Quantum yield Spectrometer C11347. The starting materials $\mathrm{IrH}_{5}\left(\mathrm{P}^{i} \mathrm{Pr}_{3}\right)_{2}{ }^{28}$ and $\mathrm{IrCl}_{3}(\mathrm{tht})_{3}{ }^{29}$ were prepared according to previously published methods. All other reagents were used as received from commercial sources.

Preparation of $\operatorname{IrH}_{2}\left\{\boldsymbol{\kappa}^{2}-N, C\right.$ - $\left.\left(q u i-\mathrm{C}_{6} \mathbf{H}_{4}\right)\right\}\left(\mathrm{P}^{i} \mathbf{P r}_{3}\right)_{2}$ (2). A yellow solution of $\mathrm{IrH}_{5}\left(\mathrm{P}^{i} \mathrm{Pr}_{3}\right)_{2}(400 \mathrm{mg}, 0.77 \mathrm{mmol})$ and 2-phenylquinoline $(158.7 \mathrm{mg}, 0.77 \mathrm{mmol})$ in toluene $(6 \mathrm{~mL})$ was refluxed one day evolving to a red solution. Toluene was concentrated to $\mathrm{Ca} \sim 1 \mathrm{~mL}$ and $\mathrm{MeOH}$ was added $(6 \mathrm{~mL})$ resulting in the precipitation of an orange solid which was washed with $\mathrm{MeOH}(2 \times 3 \mathrm{~mL})$ affording 2. Yield: $321.4 \mathrm{mg}$ (76 \%). Anal. Calcd. for $\mathrm{C}_{33} \mathrm{H}_{54} \mathrm{IrNP}_{2}$ : C, 55.13; H, 7.57; N, 1.95. Found: C, 55.11; H, 7.51; N, 1.86. IR ( $\left.\mathrm{cm}^{-1}\right): v(\mathrm{Ir}-\mathrm{H}) 2212$ (s), 1911 (s). ${ }^{1} \mathrm{H}$ NMR (400.13 MHz, $\left.\mathrm{C}_{6} \mathrm{D}_{6}, 298 \mathrm{~K}\right) \delta 10.49-10.25(\mathrm{~m}, 1 \mathrm{H}$, $\mathrm{CH}$ qui- $\left.\mathrm{C}_{6} \mathrm{H}_{4}\right), 8.62-8.44\left(\mathrm{~m}, 1 \mathrm{H}, \mathrm{CH}\right.$ qui- $\left.\mathrm{C}_{6} \mathrm{H}_{4}\right), 8.09-7.94(\mathrm{~m}, 1 \mathrm{H}$, $\mathrm{CH}$ qui- $\left.\mathrm{C}_{6} \mathrm{H}_{4}\right), 7.94-7.82\left(\mathrm{~m}, 1 \mathrm{H}, \mathrm{CH}\right.$ qui- $\left.\mathrm{C}_{6} \mathrm{H}_{4}\right), 7.68-7.47(\mathrm{~m}, 2 \mathrm{H}$, $\mathrm{CH}$ qui- $\left.\mathrm{C}_{6} \mathrm{H}_{4}\right), 7.46-7.35\left(\mathrm{~m}, 1 \mathrm{H}, \mathrm{CH} 2-\right.$ qui- $\left.\mathrm{C}_{6} \mathrm{H}_{4}\right), 7.34-7.11(\mathrm{~m}, 3 \mathrm{H}$, $\mathrm{CH}$ qui- $\left.\mathrm{C}_{6} \mathrm{H}_{4}\right), 2.04-1.85(\mathrm{~m}, 6 \mathrm{H}, \mathrm{PCH}), 0.94\left(\mathrm{dvt}, \mathrm{N}=12.8,{ }^{3} J_{\mathrm{H}-\mathrm{H}}=\right.$ 
$\left.7.0,18 \mathrm{H}, \mathrm{PCH}\left(\mathrm{CH}_{3}\right)_{2}\right), 0.89\left(\mathrm{dvt}, \mathrm{N}=12.8,{ }^{3} J_{\mathrm{H}-\mathrm{H}}=7.0,18 \mathrm{H}\right.$, $\left.\mathrm{PCH}\left(\mathrm{CH}_{3}\right)_{2}\right),-12.17\left(\mathrm{td},{ }^{2} J_{\mathrm{H}-\mathrm{P}}=20.6,{ }^{2} J_{\mathrm{H}-\mathrm{H}}=5.0,1 \mathrm{H}, \mathrm{IrH}\right),-21.20(\mathrm{td}$, $\left.\left.{ }^{2} J_{\mathrm{H}-\mathrm{P}}=18.2,{ }^{2} J_{\mathrm{H}-\mathrm{H}}=5.0,1 \mathrm{H}, \mathrm{IrH}\right) .{ }^{13} \mathrm{C}{ }^{1}{ }^{1} \mathrm{H}\right\}+\mathrm{HMBC}+\mathrm{HSQC}$ NMR $\left(100.6 \mathrm{MHz}, \mathrm{C}_{6} \mathrm{D}_{6}, 298 \mathrm{~K}\right) \delta 181.5\left(\mathrm{t},{ }^{2} J_{\mathrm{C}-\mathrm{P}}=7.0\right.$, IrC qui- $\left.\mathrm{C}_{6} \mathrm{H}_{4}\right), 171.1$ (s, Cq qui- $\left.\mathrm{C}_{6} \mathrm{H}_{4}\right), 150.1$ (s, Cq qui- $\left.\mathrm{C}_{6} \mathrm{H}_{4}\right), 150.0\left(\mathrm{~s}, \mathrm{Cq}\right.$ qui- $\left.\mathrm{C}_{6} \mathrm{H}_{4}\right)$, 144.2 (s, CH qui- $\left.\mathrm{C}_{6} \mathrm{H}_{4}\right), 138.8$ (s, $\mathrm{CH}$ qui- $\left.\mathrm{C}_{6} \mathrm{H}_{4}\right), 135.7$ (s, $\mathrm{CH}$ qui$\left.\mathrm{C}_{6} \mathrm{H}_{4}\right), 128.8\left(\mathrm{~s}, \mathrm{CH}\right.$ qui- $\left.\mathrm{C}_{6} \mathrm{H}_{4}\right), 128.7\left(\mathrm{~s}, \mathrm{CH}\right.$ qui- $\left.\mathrm{C}_{6} \mathrm{H}_{4}\right), 127.6(\mathrm{~s}, \mathrm{CH}$ qui- $\left.\mathrm{C}_{6} \mathrm{H}_{4}\right), 127.1\left(\mathrm{~s}, \mathrm{CH}\right.$ qui- $\left.\mathrm{C}_{6} \mathrm{H}_{4}\right), 126.5\left(\mathrm{~s}, \mathrm{Cq}\right.$ qui- $\left.\mathrm{C}_{6} \mathrm{H}_{4}\right), 126.2(\mathrm{~s}$, $\mathrm{CH}$ qui- $\left.\mathrm{C}_{6} \mathrm{H}_{4}\right), 119.7$ (s, CH qui- $\left.\mathrm{C}_{6} \mathrm{H}_{4}\right), 118.7\left(\mathrm{~s}, \mathrm{CH}\right.$ qui- $\left.\mathrm{C}_{6} \mathrm{H}_{4}\right), 26.8$ $\left(\mathrm{N},{ }^{1} J_{\mathrm{C}-\mathrm{P}}=27.2, \mathrm{PCH}\right), 20.1$ and 19.7 (both s, $\left.\mathrm{PCH}\left(\mathrm{CH}_{3}\right)_{2}\right) .{ }^{31} \mathrm{P}$ NMR $\left\{{ }^{1} \mathrm{H}\right\}\left(161.98 \mathrm{MHz}, \mathrm{CD}_{2} \mathrm{Cl}_{2}, 298 \mathrm{~K}\right): 25.5$ (s).

Preparation of $\left[\mathrm{IrH}\left\{\boldsymbol{\kappa}^{2}-N, C\right.\right.$ - $\left.\left.\left(\mathrm{qui}-\mathrm{C}_{6} \mathbf{H}_{4}\right)\right\}\left(\mathrm{P}^{i} \mathrm{Pr}_{3}\right)_{2}\right] \mathrm{BF}_{4}(3) . \mathrm{HBF}_{4}$ ( $52 \mu \mathrm{L}, 0.38 \mathrm{mmol}$ ) was added to an orange solution of compound 3 $(250 \mathrm{mg}, 0.35 \mathrm{mmol})$ in $\mathrm{Et}_{2} \mathrm{O}(5 \mathrm{~mL})$. This mixture was stirred at room temperature for $14 \mathrm{~h}$ and a pale orangish-yellow solid precipitated. The solution was filtered off and the solid was washed with $\mathrm{Et}_{2} \mathrm{O}(3 \times 3 \mathrm{~mL})$ yielding 3 as a pale orange solid. Yield: $165.4 \mathrm{mg}(59$ \%). Anal. Calcd. for $\mathrm{C}_{33} \mathrm{H}_{53} \mathrm{IrNP}_{2} \mathrm{BF}_{4}$ : C, 49.25; H, 6.64; N, 1.74 . Found: C, 49.39; H, 6.42; N, 1.81. IR $\left(\mathrm{cm}^{-1}\right)$ : v(Ir-H) 2248 (s), v(B-F) 1058 (vs), v(B-F) 1028 (vs). ${ }^{1} \mathrm{H}$ NMR (400.13 MHz, $\left.\mathrm{CD}_{2} \mathrm{Cl}_{2}, 298 \mathrm{~K}\right)$ $\delta$ 8.60-8.50 (m, $1 \mathrm{H}, \mathrm{CH}$ qui- $\left.\mathrm{C}_{6} \mathrm{H}_{4}\right), 8.29-8.17\left(\mathrm{~m}, 2 \mathrm{H}, \mathrm{CH}\right.$ qui- $\left.\mathrm{C}_{6} \mathrm{H}_{4}\right)$, 8.04-7.94 (m, $1 \mathrm{H}, \mathrm{CH}$ qui- $\left.\mathrm{C}_{6} \mathrm{H}_{4}\right), 7.87-7.73\left(\mathrm{~m}, 2 \mathrm{H}, \mathrm{CH}\right.$ qui- $\left.\mathrm{C}_{6} \mathrm{H}_{4}\right)$, 7.73-7.64 (m, 1H, CH qui- $\left.\mathrm{C}_{6} \mathrm{H}_{4}\right), 7.15-7.01\left(\mathrm{~m}, 2 \mathrm{H}, \mathrm{CH}\right.$ qui- $\left.\mathrm{C}_{6} \mathrm{H}_{4}\right)$, 7.0-6.89 (m, 1H, CH qui- $\left.\mathrm{C}_{6} \mathrm{H}_{4}\right), 2.39-2.22(\mathrm{~m}, 6 \mathrm{H}, \mathrm{PCH}), 1.00(\mathrm{dvt}, \mathrm{N}$ $\left.=14.1,{ }^{3} J_{\mathrm{H}-\mathrm{H}}=7.2,18 \mathrm{H}, \mathrm{PCH}\left(\mathrm{CH}_{3}\right)_{2}\right), 0.86\left(\mathrm{dvt}, \mathrm{N}=14.1,{ }^{3} J_{\mathrm{H}-\mathrm{H}}=7.2\right.$, $\left.18 \mathrm{H}, \mathrm{PCH}\left(\mathrm{CH}_{3}\right)_{2}\right),-12.88\left(\mathrm{t},{ }^{2} J_{\mathrm{H}-\mathrm{P}}=16.1,1 \mathrm{H}, \mathrm{IrH}\right) .{ }^{13} \mathrm{C}\left\{{ }^{1} \mathrm{H}\right\}+\mathrm{HMBC}$ + HSQC NMR (100.6 MHz, $\left.\mathrm{CD}_{2} \mathrm{Cl}_{2}, 298 \mathrm{~K}\right) \delta 163.2(\mathrm{~s}, \mathrm{Cq}$ qui$\left.\mathrm{C}_{6} \mathrm{H}_{4}\right), 149.4$ (s, Cq qui- $\mathrm{C}_{6} \mathrm{H}_{4}$ ), 139.4, 135.8, 131.9, 131.6 and 130.0 (all s, $5 \mathrm{CH}$ qui- $\left.\mathrm{C}_{6} \mathrm{H}_{4}\right), 128.5$ (s, Cq qui- $\left.\mathrm{C}_{6} \mathrm{H}_{4}\right), 128.3,125.9,125.0$, 123.5 (all s, $4 \mathrm{CH}$ qui- $\left.\mathrm{C}_{6} \mathrm{H}_{4}\right), 121.3\left(\mathrm{t},{ }^{2} J_{\mathrm{P}-\mathrm{C}}=6.2, \mathrm{IrC}\right.$ qui- $\left.\mathrm{C}_{6} \mathrm{H}_{4}\right), 118.5$ (s, CH qui- $\left.\mathrm{C}_{6} \mathrm{H}_{4}\right), 24.9$ (dvt, $N=27.6, \mathrm{PCH}$ ), 19.7 and 19.2 (both s, PCH $\left.\left(\mathrm{CH}_{3}\right)_{2}\right) .{ }^{31} \mathrm{P}$ NMR $\left\{{ }^{1} \mathrm{H}\right\}\left(161.98 \mathrm{MHz}, \mathrm{CD}_{2} \mathrm{Cl}_{2}, 298 \mathrm{~K}\right): 27.9$ (s). ${ }^{19} \mathrm{~F}$ NMR $\left\{{ }^{1} \mathrm{H}\right\}\left(282.33 \mathrm{MHz}, \mathrm{CD}_{2} \mathrm{Cl}_{2}, 298 \mathrm{~K}\right):-153.2(\mathrm{~s})$.

Preparation of $\operatorname{IrH}\left\{\boldsymbol{\kappa}^{2}-N, C\right.$ - $\left.\left(\mathrm{qui}-\mathrm{C}_{6} \mathbf{H}_{4}\right)\right\}(\mathbf{a c a c})\left(\mathrm{P}^{i} \mathrm{Pr}_{3}\right)$ (4). An orange suspension of compound (3) (300 $\mathrm{mg}, 0.35 \mathrm{mmol}$ ) and $\mathrm{K}(\mathrm{acac})$ $(53.2 \mathrm{mg}, 0.385 \mathrm{mmol})$ in THF $(5 \mathrm{~mL})$ was refluxed overnight. The resulting yellow solution was concentrated to dryness and toluene (20 $\mathrm{mL}$ ) was added. The yellow toluene solution was extracted to another schlenk and concentrated in vacuo to $\mathrm{Ca} \sim 1 \mathrm{~mL}$ and pentane $(6 \mathrm{~mL})$ was added resulting in the precipitation of a yellow solid. The solid was washed with pentane $(3 \times 3 \mathrm{~mL})$. Yield: $543.2 \mathrm{mg}(75 \%)$. Anal. Calcd. for $\mathrm{C}_{29} \mathrm{H}_{39} \mathrm{IrNO}_{2} \mathrm{P}: \mathrm{C}, 53.03 \mathrm{H}, 5.98 ; \mathrm{N}, 2.13$. Found: C, 53.35; $\mathrm{H}, 6.01 ; \mathrm{N}, 2.14$. IR $\left(\mathrm{cm}^{-1}\right): \mathrm{v}(\mathrm{Ir}-\mathrm{H}) 2188(\mathrm{~m}) .{ }^{1} \mathrm{H}$ NMR $(400.13 \mathrm{MHz}$, $\left.\mathrm{CD}_{2} \mathrm{Cl}_{2}, 298 \mathrm{~K}\right) \delta 8.68-8.56\left(\mathrm{~m}, 1 \mathrm{H}, \mathrm{CH}\right.$ qui- $\left.\mathrm{C}_{6} \mathrm{H}_{4}\right), 8.26-8.15(\mathrm{~m}, 1 \mathrm{H}$, $\mathrm{CH}$ qui- $\left.\mathrm{C}_{6} \mathrm{H}_{4}\right), 8.15-8.07\left(\mathrm{~m}, 1 \mathrm{H}, \mathrm{CH}\right.$ qui- $\left.\mathrm{C}_{6} \mathrm{H}_{4}\right), 7.87-7.76(\mathrm{~m}, 2 \mathrm{H}$, $\mathrm{CH}$ qui- $\left.\mathrm{C}_{6} \mathrm{H}_{4}\right), 7.72-7.63\left(\mathrm{~m}, 1 \mathrm{H}, \mathrm{CH}\right.$ qui- $\left.\mathrm{C}_{6} \mathrm{H}_{4}\right), 7.63-7.55(\mathrm{~m}, 1 \mathrm{H}$, $\mathrm{CH}$ qui- $\left.\mathrm{C}_{6} \mathrm{H}_{4}\right), 7.54-7.44\left(\mathrm{~m}, 1 \mathrm{H}, \mathrm{CH}\right.$ qui- $\left.\mathrm{C}_{6} \mathrm{H}_{4}\right), 5.06(\mathrm{~s}, 1 \mathrm{H}, \mathrm{CH}$ acac), 2.57-2.36 (m, 3H, $\mathrm{PCH}), 1.91$ and 1.36 (both s, $3 \mathrm{H}$ each, $\mathrm{CH}_{3}$ acac), $1.09\left(\mathrm{dd},{ }^{3} J_{\mathrm{H}-\mathrm{P}}=13.3,{ }^{3} J_{\mathrm{H}-\mathrm{H}}=7.2,9 \mathrm{H}, \mathrm{PCH}\left(\mathrm{CH}_{3}\right)_{2}\right), 0.91(\mathrm{dd}$, $\left.{ }^{3} J_{\mathrm{H}-\mathrm{P}}=13.0,{ }^{3} J_{\mathrm{H}-\mathrm{H}}=7.2,9 \mathrm{H}, \mathrm{PCH}\left(\mathrm{CH}_{3}\right)_{2}\right),-19.8\left(\mathrm{~d},{ }^{3} J_{\mathrm{H}-\mathrm{P}}=24.3,1 \mathrm{H}\right.$, $\mathrm{IrH}) .{ }^{13} \mathrm{C}\left\{{ }^{1} \mathrm{H}\right\}+\mathrm{HMBC}+\mathrm{HSQC}$ NMR $\left(100.6 \mathrm{MHz}, \mathrm{CD}_{2} \mathrm{Cl}_{2}, 298 \mathrm{~K}\right)$ $\delta 184.8\left(\mathrm{~s}, \mathrm{C}_{\mathrm{q}} \mathrm{acac}\right), 184.6\left(\mathrm{~d},{ }^{3} J_{\mathrm{C}-\mathrm{P}}=0.8, \mathrm{C}_{\mathrm{q}} \mathrm{acac}\right), 167.0(\mathrm{~s}, \mathrm{Cq}$ qui$\left.\mathrm{C}_{6} \mathrm{H}_{4}\right), 150.8\left(\mathrm{~d},{ }^{2} J_{\mathrm{C}-\mathrm{P}}=8.5\right.$, IrC qui- $\left.\mathrm{C}_{6} \mathrm{H}_{4}\right), 150.1$ (s, Cq qui- $\left.\mathrm{C}_{6} \mathrm{H}_{4}\right)$, 148.0 (s, Cq qui- $\left.\mathrm{C}_{6} \mathrm{H}_{4}\right), 143.5,138.0,130.0$ and 129.5 (all s, $4 \mathrm{CH}$ qui$\mathrm{C}_{6} \mathrm{H}_{4}$ ), 128.2 (s, 2CH qui- $\mathrm{C}_{6} \mathrm{H}_{4}$ ), 126.3, 126.1, 120.7, 118.3 (all s, $4 \mathrm{CH}$ qui- $\left.\mathrm{C}_{6} \mathrm{H}_{4}\right), 101.1$ (s, $\mathrm{CH}$ acac), 28.7 (s, $\left.\mathrm{CH}_{3} \mathrm{acac}\right), 27.7$ (d, ${ }^{4} J_{\mathrm{C}-\mathrm{P}}$ $\left.=5.3, \mathrm{CH}_{3} \mathrm{acac}\right), 24.3\left(\mathrm{~d},{ }^{1} J_{\mathrm{C}-\mathrm{P}}=32.1, \mathrm{PCH}\right), 19.4\left(\mathrm{~d},{ }^{2} J_{\mathrm{C}-\mathrm{P}}=0.6\right.$, $\left.\mathrm{PCHCH}_{3}\right), 18.9\left(\mathrm{~d},{ }^{2} J_{\mathrm{C}-\mathrm{P}}=1.4, \mathrm{PCHCH}_{3}\right)$. One signal corresponding to $\mathrm{Cq}$ is lost presumably due to overlapping ${ }^{31} \mathrm{P}$ NMR $\left\{{ }^{1} \mathrm{H}\right\}(282.33$ $\mathrm{MHz}, \mathrm{CD}_{2} \mathrm{Cl}_{2}, 298 \mathrm{~K}$ ): 12.5 (s).

Preparation

$$
\text { of }
$$

$\left[\operatorname{Ir}(E-C H=C H P h)\left\{\boldsymbol{c}^{2}-N, C\right.\right.$ - (qui$\left.\left.\left.\mathbf{C}_{6} \mathbf{H}_{4}\right)\right\}\left(\mathbf{P}^{i} \mathbf{P r}_{3}\right)_{2}\right] \mathbf{B F}_{4}$ (5). Phenyl acetylene (148.9 $\left.\mu \mathrm{L}, 1.356 \mathrm{mmol}\right)$ was added to orange solution of compound 3 (1091.1 mg, 1.356 $\mathrm{mmol})$ in acetone $(30 \mathrm{~mL})$. The mixture was stirred for one hour at room temperature and the solution turned dark red. The solution was concentrated to $\mathrm{Ca} \sim 1 \mathrm{~mL}$ and $\mathrm{Et}_{2} \mathrm{O}(6 \mathrm{~mL})$ was added. The resulting orange oil was stirred until an orange solid precipitated. The orange solid was washed with $\mathrm{Et}_{2} \mathrm{O}(3 \times 5 \mathrm{~mL})$ yielding 5 . Yield: $1180.4 \mathrm{mg}$ (96\%). Anal. Calcd. for $\mathrm{C}_{41} \mathrm{H}_{59} \mathrm{BF}_{4} \mathrm{IrNP}_{2}$ : C, 54.30; H, 6.56; N, 1.54 . Found: C, 54.22; H, 6.39; N, 1.52. IR ( $\left.\mathrm{cm}^{-1}\right)$ : v(B-F) 1049 (vs), v(BF) 1032 (vs). ${ }^{1} \mathrm{H}$ NMR $\left(400.13 \mathrm{MHz}, \mathrm{CD}_{2} \mathrm{Cl}_{2}, 298 \mathrm{~K}\right) \delta 9.78\left(\mathrm{~d},{ }^{2} J_{\mathrm{H}-\mathrm{H}}\right.$ $=17.7,1 \mathrm{H}, \mathrm{IrCH}), 8.61-8.55\left(\mathrm{~m}, 1 \mathrm{H}, \mathrm{CH}\right.$ qui- $\left.\mathrm{C}_{6} \mathrm{H}_{4}\right), 8.34-8.14(\mathrm{~m}$,
$3 \mathrm{H}$, $\mathrm{CH}$ qui- $\left.\mathrm{C}_{6} \mathrm{H}_{4}\right), 8.09-8.00\left(\mathrm{~m}, 1 \mathrm{H}, \mathrm{CH}\right.$ qui- $\left.\mathrm{C}_{6} \mathrm{H}_{4}\right), 7.91-7.68(\mathrm{~m}$, $3 \mathrm{H}, \mathrm{CH}$ qui- $\left.\mathrm{C}_{6} \mathrm{H}_{4}\right), 7.53-7.35(\mathrm{~m}, 4 \mathrm{H}, \mathrm{CH} \mathrm{Ph}), 7.26-7.10(\mathrm{~m}, 3 \mathrm{H}, 2$ $\mathrm{CH}$ qui- $\mathrm{C}_{6} \mathrm{H}_{4}$ and $\left.\mathrm{CH} \mathrm{Ph}\right), 6.73\left(\mathrm{~d},{ }^{3} \mathrm{~J}_{\mathrm{H}-\mathrm{H}}=17.7,1 \mathrm{H}, \mathrm{IrCHCH}\right), 2.46-$ $2.26(\mathrm{br}, 6 \mathrm{H}, \mathrm{PCH}), 0.90\left(\mathrm{dvt}, \mathrm{N}=13.7,{ }^{3} J_{\mathrm{H}-\mathrm{H}}=6.9,18 \mathrm{H}\right.$, $\left.\mathrm{PCH}\left(\mathrm{CH}_{3}\right)_{2}\right), 0.87\left(\mathrm{dvt}, \mathrm{N}=13.7,{ }^{3} J_{\mathrm{H}-\mathrm{H}}=6.9,18 \mathrm{H}, \mathrm{PCH}\left(\mathrm{CH}_{3}\right)_{2}\right)$. ${ }^{13} \mathrm{C}\left\{{ }^{1} \mathrm{H}\right\}+\mathrm{HMBC}+\mathrm{HSQC}$ NMR $\left(100.6 \mathrm{MHz}, \mathrm{CD}_{2} \mathrm{Cl}_{2}, 298 \mathrm{~K}\right) \delta$ 163.8 (s, Cq qui- $\left.\mathrm{C}_{6} \mathrm{H}_{4}\right), 149.5$ (s, Cq qui- $\left.\mathrm{C}_{6} \mathrm{H}_{4}\right), 141.4(\mathrm{~s}, \mathrm{Cq}$ qui$\left.\mathrm{C}_{6} \mathrm{H}_{4}\right), 140.6\left(\mathrm{t},{ }^{4} J_{\mathrm{C}-\mathrm{P}}=1.7, \mathrm{Cq} \mathrm{Ph}\right), 140.5\left(\mathrm{~s}, \mathrm{CH}\right.$ qui-C $\left.\mathrm{C}_{6} \mathrm{H}_{4}\right), 134.8(\mathrm{t}$, $\left.{ }^{3} J_{\mathrm{C}-\mathrm{P}}=10.8, \mathrm{IrCH}\right), 133.9\left(\mathrm{~s}, \mathrm{CH}\right.$ qui-C $\left.\mathrm{C}_{6} \mathrm{H}_{4}\right), 133.6\left(\mathrm{t},{ }^{4} J_{\mathrm{C}-\mathrm{P}}=3.5\right.$, $\mathrm{IrCHCH}), 132.0$ and 131.1 (both s, $2 \mathrm{CH}$ qui- $\left.\mathrm{C}_{6} \mathrm{H}_{4}\right), 130.4(\mathrm{~s}, 2 \mathrm{CH}$ qui- $\mathrm{C}_{6} \mathrm{H}_{4}$ indirectly assigned through $\left.\mathrm{HSQC}\right), 129.3(\mathrm{~s}, \mathrm{CH} \mathrm{Ph}), 129.0$ $\left(\mathrm{s}, \mathrm{C}_{\mathrm{q}}\right.$ qui- $\left.\mathrm{C}_{6} \mathrm{H}_{4}\right), 128.7,126.8,126.1\left(\mathrm{~s}, 3 \mathrm{CH}\right.$ qui- $\left.\mathrm{C}_{6} \mathrm{H}_{4}\right), 125.4(\mathrm{~s}, \mathrm{CH}$ $\mathrm{Ph}), 125.2(\mathrm{~s}, \mathrm{CH} \mathrm{Ph}), 124.8\left(\mathrm{~s}, \mathrm{CH}\right.$ qui- $\left.\mathrm{C}_{6} \mathrm{H}_{4}\right), 119.0\left(\mathrm{t},{ }^{2} J_{\mathrm{C}-\mathrm{P}}=6.4\right.$, $\mathrm{IrC}$ qui- $\left.\mathrm{C}_{6} \mathrm{H}_{4}\right), 23.5$ (dvt, $\mathrm{N}=25.6, \mathrm{PCH}$ ), 20.1 and 19.7 (both $\mathrm{s}$, $\left.\mathrm{PCH}\left(\mathrm{CH}_{3}\right)_{2}\right) .{ }^{31} \mathrm{P}$ NMR $\left\{{ }^{1} \mathrm{H}\right\}\left(161.98 \mathrm{MHz}, \mathrm{CD}_{2} \mathrm{Cl}_{2}, 298 \mathrm{~K}\right): 7.0$ (s). ${ }^{19} \mathrm{~F}$ NMR $\left\{{ }^{1} \mathrm{H}\right\}\left(282.33 \mathrm{MHz}, \mathrm{CD}_{2} \mathrm{Cl}_{2}, 298 \mathrm{~K}\right):-152.4(\mathrm{~s})$.

Preparation of $\left[\operatorname{Ir}\left(E-\mathrm{CH}=\mathrm{CH}_{2}\right)\left\{\boldsymbol{\kappa}^{2}-N, C-\left(\right.\right.\right.$ qui- $\left.\left.\left.\mathrm{C}_{6} \mathrm{H}_{4}\right)\right\}\left(\mathrm{P}^{i} \mathrm{Pr}_{3}\right)_{2}\right] \mathrm{BF}_{4}$ (6). An orange suspension of compound $3(1190 \mathrm{mg}, 1.48 \mathrm{mmol})$ in THF $(20 \mathrm{~mL})$ was stirred under acetylene atmosphere $(1 \mathrm{~atm})$ at room temperature. The mixture was stirred at room temperature for 20 minutes and a dark suspension was formed. The dark suspension was extracted through celites and the resulting red solution was concentrated to $\mathrm{Ca} \sim 1 \mathrm{~mL}$. Cold $\mathrm{Et}_{2} \mathrm{O}(5 \mathrm{ml})$ was added and an orange solid precipitated. The orange solid was washed with $\mathrm{Et}_{2} \mathrm{O}(4 \times 3 \mathrm{ml})$. Yield: $808.6 \mathrm{mg}$ (66 \%). Anal. Calcd. for $\mathrm{C}_{35} \mathrm{H}_{55} \mathrm{BF}_{4} \mathrm{IrNP}_{2}$ : C, 50.60; $\mathrm{H}$, 6.67; N, 1.69. Found: C, 50.98; H, 6.28; N, 1.78. IR $\left(\mathrm{cm}^{-1}\right): v(\mathrm{~B}-\mathrm{F})$ 1055 (vs), v(B-F) 1023 (vs). ${ }^{1} \mathrm{H}$ NMR (300.13 MHz, $\mathrm{CD}_{2} \mathrm{Cl}_{2}, 298 \mathrm{~K}$ ) $\delta 9.30\left(\mathrm{tdd},{ }^{3} J_{\mathrm{H}-\mathrm{H}}=15.7,{ }^{3} J_{\mathrm{H}-\mathrm{H}}=15.7,{ }^{3} J_{\mathrm{H}-\mathrm{P}}=1.6,1 \mathrm{H}, \mathrm{IrCH}\right), 8.60-8.50$ $\left(\mathrm{m}, 1 \mathrm{H}, \mathrm{CH}\right.$ qui- $\left.\mathrm{C}_{6} \mathrm{H}_{4}\right), 8.29-8.11\left(\mathrm{~m}, 3 \mathrm{H}, \mathrm{CH}\right.$ qui- $\left.\mathrm{C}_{6} \mathrm{H}_{4}\right), 8.06-7.95$ $\left(\mathrm{m}, 1 \mathrm{H}, \mathrm{CH}\right.$ qui- $\left.\mathrm{C}_{6} \mathrm{H}_{4}\right), 7.89-7.79\left(\mathrm{~m}, 1 \mathrm{H}, \mathrm{CH}\right.$ qui- $\left.\mathrm{C}_{6} \mathrm{H}_{4}\right), 7.75-7.63$ $\left(\mathrm{m}, 2 \mathrm{H}, \mathrm{CH}\right.$ qui- $\left.\mathrm{C}_{6} \mathrm{H}_{4}\right), 7.24-7.15\left(\mathrm{~m}, 1 \mathrm{H}, \mathrm{CH}\right.$ qui- $\left.\mathrm{C}_{6} \mathrm{H}_{4}\right), 7.15-7.04$ (m, 1H, CH), 6.21-5.57 (br, 2H, IrCHCH $H_{2}, 2.54-2.37$ (m, 6H, PCH), $0.88\left(\mathrm{dvt}, N=14.2,{ }^{3} J_{\mathrm{H}-\mathrm{H}}=7.2,18 \mathrm{H}, \mathrm{PCH}\left(\mathrm{CH}_{3}\right)_{2}\right), 0.83(\mathrm{dvt}, \mathrm{N}=$ $\left.13.4,{ }^{3} J_{\mathrm{H}-\mathrm{H}}=7.2,18 \mathrm{H}, \mathrm{PCH}\left(\mathrm{CH}_{3}\right)_{2}\right)$. Note; the signal corresponding to $\mathrm{IrCHCH}_{2}$ splits at $223 \mathrm{~K}$ into two doublets at $6.14\left(\mathrm{~d},{ }^{3} \mathrm{~J}_{\mathrm{H}-\mathrm{H}}=12.7\right)$ and $5.45\left(\mathrm{~d},{ }^{3} \mathrm{~J}_{\mathrm{H}-\mathrm{H}}=18.6\right) \cdot{ }^{13} \mathrm{C}\left\{{ }^{1} \mathrm{H}\right\}+\mathrm{HMBC}+\mathrm{HSQC}$ NMR $(75.47$ $\mathrm{MHz}, \mathrm{CD}_{2} \mathrm{Cl}_{2}, 298 \mathrm{~K}$ ) $\delta 163.9$ (s, Cq qui- $\mathrm{C}_{6} \mathrm{H}_{4}$ ), 149.6 (s, Cq qui$\left.\mathrm{C}_{6} \mathrm{H}_{4}\right), 141.8\left(\mathrm{t},{ }^{3} J_{\mathrm{C}-\mathrm{P}}=10.1, \mathrm{IrCH}\right), 141.4\left(\mathrm{~s}, \mathrm{Cq}\right.$ qui- $\left.\mathrm{C}_{6} \mathrm{H}_{4}\right), 140.4$, $134.1,131.9,131.0,130.4,128.7,126.7,125.3,125.1$ (all s, 9CH qui$\left.\mathrm{C}_{6} \mathrm{H}_{4}\right), 121.2\left(\mathrm{t},{ }^{3} J_{\mathrm{C}-\mathrm{P}}=3.3, \mathrm{IrCHCH}_{2}\right), 119.1\left(\mathrm{t},{ }^{2} J_{\mathrm{C}-\mathrm{P}}=6.4\right.$, IrC qui$\left.\mathrm{C}_{6} \mathrm{H}_{4}\right), 118.6\left(\mathrm{~s}, \mathrm{CH}\right.$ qui- $\left.\mathrm{C}_{6} \mathrm{H}_{4}\right), 23.7\left(\mathrm{dvt},{ }^{1} J_{\mathrm{C}-\mathrm{P}}=25.6, \mathrm{PCH}\right), 20.4$ and 20.0 (both s, $\left.\mathrm{PCH}\left(\mathrm{CH}_{3}\right)_{2}\right) .{ }^{31} \mathrm{P}$ NMR $\left\{{ }^{1} \mathrm{H}\right\}\left(161.98 \mathrm{MHz}, \mathrm{CD}_{2} \mathrm{Cl}_{2}, 298\right.$ $\mathrm{K}): 6.5(\mathrm{~s}) .{ }^{19} \mathrm{~F}$ NMR $\left\{{ }^{1} \mathrm{H}\right\}\left(282.33 \mathrm{MHz}, \mathrm{CD}_{2} \mathrm{Cl}_{2}, 298 \mathrm{~K}\right):-153.4(\mathrm{~s})$.

\section{Preparation of $\operatorname{Ir}(E-C H=C H P h)\left\{\boldsymbol{c}^{2}-N, C\right.$-(qui-} $\left.\mathbf{C}_{6} \mathbf{H}_{4}\right)$ \}(acac) $\left(\mathbf{P}^{i} \mathbf{P r}_{3}\right)$ (7). A KOH solution in $\mathrm{MeOH}(2.55 \mathrm{~mL}, 0.258$ M) was added to acetylacetone $(68 \mu \mathrm{L}, 0.66 \mathrm{mmol})$. The solution was stirred for 10 minutes and then it was added to an orange suspension of compound 5 ( $400 \mathrm{mg}, 0.44 \mathrm{mmol})$ in THF $(15 \mathrm{~mL})$. The mixture was stirred overnight and it turned to and orange solution. The THF was concentrated to dryness and dichloromethane $(20 \mathrm{~mL})$ was added. The resulting orange solution was extracted and concentrated to dryness in vacuo to $\mathrm{Ca} \sim 1 \mathrm{~mL}$ and Cold pentane $(5 \mathrm{~mL})$ was added. The resulting yellow solid was washed with pentane $(3 \times 3 \mathrm{~mL})$. Yield: $265.0 \mathrm{mg}(70 \%)$. Anal. Calcd. for $\mathrm{C}_{37} \mathrm{H}_{45} \mathrm{IrNO}_{2} \mathrm{P}: \mathrm{C}, 58.56 ; \mathrm{H}, 5.98$; $\mathrm{N}, 1.85$. Found: C, 58.25; H, 6.18; N, 2.06. ${ }^{1} \mathrm{H}$ NMR $(400.13 \mathrm{MHz}$, $\left.\mathrm{CD}_{2} \mathrm{Cl}_{2}, 298 \mathrm{~K}\right) \delta 9.19\left(\mathrm{dd},{ }^{3} J_{\mathrm{H}-\mathrm{H}}=16.2,{ }^{3} J_{\mathrm{H}-\mathrm{P}}=4.9,1 \mathrm{H}, \mathrm{IrCH}\right), 8.79-$ $8.72\left(\mathrm{~m}, 1 \mathrm{H}, \mathrm{CH}\right.$ qui- $\left.\mathrm{C}_{6} \mathrm{H}_{4}\right), 8.24-8.17\left(\mathrm{~m}, 1 \mathrm{H}, \mathrm{CH}\right.$ qui- $\left.\mathrm{C}_{6} \mathrm{H}_{4}\right), 8.18-$ $8.11\left(\mathrm{~m}, 1 \mathrm{H}, \mathrm{CH}\right.$ qui- $\left.\mathrm{C}_{6} \mathrm{H}_{4}\right), 7.94-7.85\left(\mathrm{~m}, 2 \mathrm{H}, \mathrm{CH}\right.$ qui- $\left.\mathrm{C}_{6} \mathrm{H}_{4}\right), 7.86-$ $7.80\left(\mathrm{~m}, 1 \mathrm{H}, \mathrm{CH}\right.$ qui- $\left.\mathrm{C}_{6} \mathrm{H}_{4}\right), 7.68-7.60\left(\mathrm{~m}, 1 \mathrm{H}, \mathrm{CH}\right.$ qui- $\left.\mathrm{C}_{6} \mathrm{H}_{4}\right), 7.60-$ $7.46\left(\mathrm{~m}, 2 \mathrm{H}, \mathrm{CH}\right.$ qui- $\left.\mathrm{C}_{6} \mathrm{H}_{4}\right), 7.34-7.26(\mathrm{~m}, 2 \mathrm{H}, \mathrm{CH} \mathrm{Ph}), 7.26-7.18(\mathrm{~m}$, $2 \mathrm{H}, \mathrm{CH} \mathrm{Ph}), 7.14-7.04(\mathrm{~m}, 1 \mathrm{H}, \mathrm{CH} \mathrm{Ph}), 7.04-6.98(\mathrm{~m}, 1 \mathrm{H}, \mathrm{CH}$ qui$\left.\mathrm{C}_{6} \mathrm{H}_{4}\right), 6.26\left(\mathrm{~d},{ }^{3} \mathrm{~J}_{\mathrm{H}-\mathrm{H}}=16.2,1 \mathrm{H}, \mathrm{IrCHCH}\right), 4.93(\mathrm{~s}, 1 \mathrm{H}, \mathrm{CH}$ acac $)$, 2.65-2.50 (m, 3H, $\mathrm{PCH}), 1.97$ and 1.32 (both s, $3 \mathrm{H}$ each, both $\mathrm{CH}_{3}$ acac), $1.14\left(\mathrm{dd},{ }^{3} J_{\mathrm{H}-\mathrm{P}}=12.6,{ }^{3} J_{\mathrm{H}-\mathrm{H}}=7.2,9 \mathrm{H}, \mathrm{PCH}\left(\mathrm{CH}_{3}\right)_{2}\right), 1.05(\mathrm{dd}$, $\left.{ }^{3} J_{\mathrm{H}-\mathrm{P}}=13.1,{ }^{3} J_{\mathrm{H}-\mathrm{H}}=7.2,9 \mathrm{H}, \mathrm{PCH}\left(\mathrm{CH}_{3}\right)_{2}\right) \cdot{ }^{13} \mathrm{C}\left\{{ }^{1} \mathrm{H}\right\}+\mathrm{HMBC}+\mathrm{HSQC}$ NMR (100.61 MHz, $\left.\mathrm{CD}_{2} \mathrm{Cl}_{2}, 298 \mathrm{~K}\right) \delta 184.1$ (s, Cq acac), 183.7 (d, ${ }^{3} J_{\mathrm{C}-\mathrm{P}}=1.2, \mathrm{Cq}$ acac $), 167.8\left(\mathrm{~s}, \mathrm{Cq}\right.$ qui- $\left.\mathrm{C}_{6} \mathrm{H}_{4}\right), 149.5\left(\mathrm{~s}, \mathrm{Cq}\right.$ qui- $\left.\mathrm{C}_{6} \mathrm{H}_{4}\right)$, $148.8\left(\mathrm{~d},{ }^{2} J_{\mathrm{C}-\mathrm{P}}=8.6, \mathrm{IrC}\right.$ qui- $\left.\mathrm{C}_{6} \mathrm{H}_{4}\right), 148.8\left(\mathrm{~s}, \mathrm{Cq}\right.$ qui- $\left.\mathrm{C}_{6} \mathrm{H}_{4}\right), 142.9(\mathrm{~s}$, $\mathrm{Cq} \mathrm{Ph}), 139.2\left(\mathrm{~s}, \mathrm{CH}\right.$ qui- $\left.\mathrm{C}_{6} \mathrm{H}_{4}\right), 139.2\left(\mathrm{~s}, \mathrm{CH}\right.$ qui- $\left.\mathrm{C}_{6} \mathrm{H}_{4}\right), 132.2(\mathrm{~d}$, $\left.{ }^{3} J_{\mathrm{C}-\mathrm{P}}=9.6, \operatorname{IrC} \operatorname{IrCH}\right), 132.1(\mathrm{~s}, \operatorname{IrCHCH}), 130.1\left(\mathrm{~s}, \mathrm{CH}\right.$ qui-C $\left.\mathrm{C}_{6} \mathrm{H}_{4}\right)$, $128.9\left(\mathrm{~s}, \mathrm{CH}\right.$ qui- $\left.\mathrm{C}_{6} \mathrm{H}_{4}\right), 128.6(\mathrm{~s}, \mathrm{CH} \mathrm{Ph}), 128.5\left(\mathrm{~s}, \mathrm{CH}\right.$ qui- $\left.\mathrm{C}_{6} \mathrm{H}_{4}\right)$ $128.0\left(\mathrm{~s}, \mathrm{CH}\right.$ qui- $\left.\mathrm{C}_{6} \mathrm{H}_{4}\right), 127.8\left(\mathrm{~s}, \mathrm{Cq}\right.$ qui- $\left.\mathrm{C}_{6} \mathrm{H}_{4}\right), 126.6(\mathrm{~s}, \mathrm{CH}$ qui- 
$\left.\mathrm{C}_{6} \mathrm{H}_{4}\right), 126.2\left(\mathrm{~s}, \mathrm{CH}\right.$ qui- $\left.\mathrm{C}_{6} \mathrm{H}_{4}\right), 125.2(\mathrm{~s}, \mathrm{CH} \mathrm{Ph}), 124.3(\mathrm{~s}, \mathrm{CH} \mathrm{Ph})$, 122.0 (s, $\mathrm{CH}$ qui- $\mathrm{C}_{6} \mathrm{H}_{4}$ ), 118.4 (s, $\mathrm{CH}$ qui- $\left.\mathrm{C}_{6} \mathrm{H}_{4}\right), 100.2$ (s, $\mathrm{CH}$ acac), 28.7 (s, $\mathrm{CH}_{3} \mathrm{acac}$ ), 28.1 (d, $\left.{ }^{4} J_{\mathrm{C}-\mathrm{P}}=5.8, \mathrm{CH}_{3} \mathrm{acac}\right), 25.5\left(\mathrm{~d},{ }^{1} J_{\mathrm{C}-\mathrm{P}}=\right.$ 30.3, PCH), $20.1\left(\mathrm{~d},{ }^{2} J_{\mathrm{C}-\mathrm{P}}=3.0, \operatorname{PCH}\left(\mathrm{CH}_{3}\right)_{2}\right), 19.7\left(\mathrm{~s}, \mathrm{PCH}\left(\mathrm{CH}_{3}\right)_{2}\right)$. ${ }^{31} \mathrm{P}$ NMR $\left\{{ }^{1} \mathrm{H}\right\}\left(161.98 \mathrm{MHz}, \mathrm{CD}_{2} \mathrm{Cl}_{2}, 298 \mathrm{~K}\right):-8.8(\mathrm{~s})$.

Preparation of $\operatorname{Ir}\left(E-\mathrm{CH}=\mathrm{CH}_{2}\right)\left\{\boldsymbol{\kappa}^{2}-\mathrm{N}, \mathrm{C}-\left(\mathrm{qui}-\mathrm{C}_{6} \mathrm{H}_{4}\right)\right\}(\mathrm{acac})\left(\mathrm{P}^{i} \mathrm{Pr}_{3}\right)$ (8). A KOH solution in $\mathrm{MeOH}(5.5 \mathrm{~mL}, 0.258 \mathrm{M})$ was added to acetylacetone $(150 \mu \mathrm{L}, 1.46 \mathrm{mmol})$. The solution was stirred for 10 minutes and then it was added to an orange suspension of compound 6 ( $808.6 \mathrm{mg}, 0.973 \mathrm{mmol})$ in THF $(25 \mathrm{~mL})$. The mixture was stirred overnight and it turned and reddish orange solution. The THF was concentrated to dryness and dichloromethane $(20 \mathrm{~mL})$ was added. The resulting reddish orange solution was extracted and concentrated to $\mathrm{Ca} \sim 1 \mathrm{~mL}$ in vacuo. Cold pentane $(5 \mathrm{~mL})$ was added to the resulting orange solution and a yellow solid precipitated. The solid was washed with pentane $(3 \times 3 \mathrm{~mL})$. Yield: $455.8 \mathrm{mg}(60 \%)$. Anal. Calcd. for $\mathrm{C}_{31} \mathrm{H}_{41} \mathrm{IrNO}_{2} \mathrm{P}: \mathrm{C}, 54.53 ; \mathrm{H}, 6.05 ; \mathrm{N}, 2.05$. Found: C, 54.15; H, 6.10; $\mathrm{N}, 1.76 .{ }^{1} \mathrm{H}$ NMR $\left(300.13 \mathrm{MHz}, \mathrm{CD}_{2} \mathrm{Cl}_{2}, 298 \mathrm{~K}\right) \delta 8.72-8.63(\mathrm{~m}, 1 \mathrm{H}$, $\mathrm{CH}$ qui- $\left.\mathrm{C}_{6} \mathrm{H}_{4}\right), 8.39$ (ddd, ${ }^{3} \mathrm{~J}_{\mathrm{H}-\mathrm{H}}=17.4,{ }^{2} J_{\mathrm{H}-\mathrm{H}}=10.5,{ }^{3} \mathrm{~J}_{\mathrm{H}-\mathrm{P}}=4.9,1 \mathrm{H}$, $\mathrm{IrCH}), 8.22-8.08\left(\mathrm{~m}, 2 \mathrm{H}, \mathrm{CH}\right.$ qui- $\left.\mathrm{C}_{6} \mathrm{H}_{4}\right), 7.94-7.77(\mathrm{~m}, 3 \mathrm{H}, \mathrm{CH}$ qui$\left.\mathrm{C}_{6} \mathrm{H}_{4}\right), 7.66-7.56\left(\mathrm{~m}, 1 \mathrm{H}, \mathrm{CH}\right.$ qui- $\left.\mathrm{C}_{6} \mathrm{H}_{4}\right), 7.55-7.45(\mathrm{~m}, 2 \mathrm{H}, \mathrm{CH}$ qui$\left.\mathrm{C}_{6} \mathrm{H}_{4}\right), 7.11-7.00\left(\mathrm{~m}, 1 \mathrm{H}, \mathrm{CH}\right.$ qui- $\left.\mathrm{C}_{6} \mathrm{H}_{4}\right), 5.47\left(\mathrm{ddd},{ }^{3} J_{\mathrm{H}-\mathrm{H}}=10.5,{ }^{2} J_{\mathrm{H}-\mathrm{H}}\right.$ $\left.\left.=3.1,{ }^{3} J_{\mathrm{H}-\mathrm{P}}=1.2,1 \mathrm{H}, \mathrm{IrCHCH}\right)_{2}\right), 4.91\left(\mathrm{dd},{ }^{3} J_{\mathrm{H}-\mathrm{H}}=17.4,{ }^{2} J_{\mathrm{H}-\mathrm{H}}=3.1\right.$, $\left.1 \mathrm{H}, \mathrm{IrCHCH}_{2}\right) 4.92$ (s, 1H, CH acac), 2.64-2.43 (m, 3H, PCH), 1.94 and 1.26 (both s, $3 \mathrm{H}$ each, both $\left.\mathrm{CH}_{3} \mathrm{acac}\right), 1.09\left(\mathrm{dd},{ }^{3} J_{\mathrm{H}-\mathrm{P}}=12.6,{ }^{3} J_{\mathrm{H}-}\right.$ $\left.{ }_{\mathrm{H}}=7.2,9 \mathrm{H}, \mathrm{PCH}\left(\mathrm{CH}_{3}\right)_{2}\right), 0.99\left(\mathrm{dd}^{3} J_{\mathrm{H}-\mathrm{P}}=13.0,{ }^{3} J_{\mathrm{H}-\mathrm{H}}=7.2,9 \mathrm{H}\right.$, $\left.\mathrm{PCH}\left(\mathrm{CH}_{3}\right)_{2}\right) \cdot{ }^{13} \mathrm{C}\left\{{ }^{1} \mathrm{H}\right\}+\mathrm{HMBC}+\mathrm{HSQC}$ NMR $75.47 \mathrm{MHz}, \mathrm{CD}_{2} \mathrm{Cl}_{2}$, $298 \mathrm{~K}) \delta 183.7(\mathrm{~s}, \mathrm{Cq} \mathrm{acac}), 183.3\left(\mathrm{~d},{ }^{3} J_{\mathrm{C}-\mathrm{P}}=1.4\right.$, Cq acac), $167.2(\mathrm{~s}$, $\mathrm{Cq}$ qui- $\left.\mathrm{C}_{6} \mathrm{H}_{4}\right), 149.6\left(\mathrm{~s}, \mathrm{Cq}\right.$ qui- $\left.\mathrm{C}_{6} \mathrm{H}_{4}\right), 148.9\left(\mathrm{~d},{ }^{2} J_{\mathrm{C}-\mathrm{P}}=8.6\right.$, IrC qui$\left.\mathrm{C}_{6} \mathrm{H}_{4}\right), 148.8\left(\mathrm{~s}, \mathrm{Cq}\right.$ qui- $\left.\mathrm{C}_{6} \mathrm{H}_{4}\right), 138.9\left(\mathrm{~s}, \mathrm{CH}\right.$ qui- $\left.\mathrm{C}_{6} \mathrm{H}_{4}\right), 138.0(\mathrm{~s}, \mathrm{CH}$ qui- $\left.\mathrm{C}_{6} \mathrm{H}_{4}\right), 136.4\left(\mathrm{~d},{ }^{3} J_{\mathrm{C}-\mathrm{P}}=9.2, \mathrm{IrCH}\right), 130.0\left(\mathrm{~s}, \mathrm{CH}\right.$ qui- $\left.\mathrm{C}_{6} \mathrm{H}_{4}\right), 128.5$ (s, $\mathrm{CH}$ qui- $\left.\mathrm{C}_{6} \mathrm{H}_{4}\right), 128.4\left(\mathrm{~s}, \mathrm{CH}\right.$ qui- $\left.\mathrm{C}_{6} \mathrm{H}_{4}\right), 128.1\left(\mathrm{~s}, \mathrm{CH}\right.$ qui- $\left.\mathrm{C}_{6} \mathrm{H}_{4}\right)$, $127.8\left(\mathrm{~s}, \mathrm{Cq}\right.$ qui- $\left.\mathrm{C}_{6} \mathrm{H}_{4}\right), 126.5\left(\mathrm{~s}, \mathrm{Cq}\right.$ qui- $\left.\mathrm{C}_{6} \mathrm{H}_{4}\right), 126.2(\mathrm{~s}, \mathrm{CH}$ qui$\left.\mathrm{C}_{6} \mathrm{H}_{4}\right), 121.9$ (s, $\mathrm{CH}$ qui- $\left.\mathrm{C}_{6} \mathrm{H}_{4}\right), 118.4\left(\mathrm{~s}, \mathrm{CH}\right.$ qui- $\left.\mathrm{C}_{6} \mathrm{H}_{4}\right), 116.3(\mathrm{~s}$, $\mathrm{IrCHCH}_{2}$ ), 100.0 (s, CH acac), $28.7\left(\mathrm{~s}, \mathrm{CH}_{3} \mathrm{acac}\right), 28.1\left(\mathrm{~d},{ }^{4} J_{\mathrm{C}-\mathrm{P}}=5.9\right.$ $\mathrm{CH}_{3}$ acac), $25.5\left(\mathrm{~d},\left(\mathrm{~d},{ }^{1} J_{\mathrm{C}-\mathrm{P}}=30.3 \mathrm{PCH}\right), 20.2\left(\mathrm{~d},{ }^{2} J_{\mathrm{C}-\mathrm{P}}=2.9\right.\right.$ $\left.\operatorname{PCH}\left(\mathrm{CH}_{3}\right)_{2}\right), 18.8\left(\mathrm{~d},{ }^{2} J_{\mathrm{C}-\mathrm{P}}=1.3 \mathrm{PCH}\left(\mathrm{CH}_{3}\right)_{2}\right) .{ }^{31} \mathrm{P}$ NMR $\left\{{ }^{1} \mathrm{H}\right\}(121.49$ $\left.\mathrm{MHz}, \mathrm{CD}_{2} \mathrm{Cl}_{2}, 298 \mathrm{~K}\right):-8.9$ (s).

Preparation of $\operatorname{IrCl}_{2}\left\{\boldsymbol{\kappa}^{2}-N, C\right.$-(qui- $\left.\left.\mathrm{C}_{6} \mathrm{H}_{4}\right)\right\}\left(\mathrm{P}^{i} \operatorname{Pr}_{3}\right) \quad$ (10). $\quad \mathrm{P}^{i} \operatorname{Pr}_{3}$ $(170.0 \mu \mathrm{L}, 0.888 \mathrm{mmol})$ was added to a yellow suspension of $\mathrm{IrCl}_{3}(\mathrm{THT})_{3}(500 \mathrm{mg}, 0.888 \mathrm{mmol})$ in decaline $(5 \mathrm{~mL})$. The resulting yellow suspension was heated for 90 minutes at $185^{\circ} \mathrm{C}$ and turned to a red solution. 2-Phenylquinoline $(120.3 \mathrm{mg}, 0.533 \mathrm{mmol})$ was added and the resulting mixture was refluxed overnight. The resulting orange solid was separated by decantation. The solid was washed with pentane $(3 \times 4 \mathrm{~mL})$. Yield: $379.8 \mathrm{mg}(58 \%)$. Anal. Calcd. for $\mathrm{C}_{24} \mathrm{H}_{31} \mathrm{Cl}_{2} \mathrm{IrNP}: \mathrm{C}$, 45.93; H, 4.98; N, 2.23. Found: C, 45.61; H, 4.97; $\mathrm{N}, 2.32 .{ }^{1} \mathrm{H}$ NMR $\left(300 \mathrm{MHz}, \mathrm{CD}_{2} \mathrm{Cl}_{2}, 298 \mathrm{~K}\right) \delta 8.50-8.33(\mathrm{~m}, 1 \mathrm{H}, \mathrm{CH}$ qui- $\left.\mathrm{C}_{6} \mathrm{H}_{4}\right), 8.21-8.10\left(\mathrm{~m}, 1 \mathrm{H}, \mathrm{CH}\right.$ qui- $\left.\mathrm{C}_{6} \mathrm{H}_{4}\right), 7.94-7.76(\mathrm{~m}, 4 \mathrm{H}, \mathrm{CH}$ qui- $\left.\mathrm{C}_{6} \mathrm{H}_{4}\right), 7.69-7.57\left(\mathrm{~m}, 1 \mathrm{H}, \mathrm{CH}\right.$ qui- $\left.\mathrm{C}_{6} \mathrm{H}_{4}\right), 7.58-7.47(\mathrm{~m}, 1 \mathrm{H}, \mathrm{CH}$ qui- $\left.\mathrm{C}_{6} \mathrm{H}_{4}\right), 7.09-7.01\left(\mathrm{~m}, 1 \mathrm{H}, \mathrm{CH}\right.$ qui- $\left.\mathrm{C}_{6} \mathrm{H}_{4}\right), 7.02-6.94(\mathrm{~m}, 1 \mathrm{H}, \mathrm{CH}$ qui- $\left.\mathrm{C}_{6} \mathrm{H}_{4}\right), 2.49-2.31(\mathrm{~m}, 3 \mathrm{H}, \mathrm{PCH}), 1.03\left(\mathrm{dd},{ }^{3} \mathrm{~J}_{\mathrm{H}-\mathrm{P}}=14.2,{ }^{3} \mathrm{~J}_{\mathrm{H}-\mathrm{H}}=7.2\right.$, $\left.9 \mathrm{H}, \mathrm{PCHCH} H_{3}\right), 1.03\left(\mathrm{dd},{ }^{3} J_{\mathrm{H}-\mathrm{P}}=13.4,{ }^{3} J_{\mathrm{H}-\mathrm{H}}=7.2,9 \mathrm{H}, \mathrm{PCHCH}_{3}\right)$. ${ }^{13} \mathrm{C}\left\{{ }^{1} \mathrm{H}\right\}+\mathrm{HMBC}+\mathrm{HSQC}$ NMR $\left(75.47 \mathrm{MHz}, \mathrm{CD}_{2} \mathrm{Cl}_{2}, 298 \mathrm{~K}\right) \delta$ 167.8 (s, Cq qui- $\left.\mathrm{C}_{6} \mathrm{H}_{4}\right), 149.3$ (s, Cq qui- $\left.\mathrm{C}_{6} \mathrm{H}_{4}\right), 144.2$ (s, Cq qui$\left.\mathrm{C}_{6} \mathrm{H}_{4}\right), 139.6\left(\mathrm{~s}, \mathrm{CH}\right.$ qui- $\left.\mathrm{C}_{6} \mathrm{H}_{4}\right), 137.8\left(\mathrm{~s}, \mathrm{CH}\right.$ qui- $\left.\mathrm{C}_{6} \mathrm{H}_{4}\right), 131.6(\mathrm{~s}, \mathrm{CH}$ qui- $\left.\mathrm{C}_{6} \mathrm{H}_{4}\right), 130.6\left(\mathrm{~s}, \mathrm{CH}\right.$ qui- $\left.\mathrm{C}_{6} \mathrm{H}_{4}\right), 129.4\left(\mathrm{~s}, \mathrm{CH}\right.$ qui- $\left.\mathrm{C}_{6} \mathrm{H}_{4}\right), 128.3(\mathrm{~s}$, $\mathrm{Cq}$ qui- $\left.\mathrm{C}_{6} \mathrm{H}_{4}\right), 127.6\left(\mathrm{~s}, \mathrm{CH}\right.$ qui- $\left.\mathrm{C}_{6} \mathrm{H}_{4}\right), 126.2$ (s, $2 \mathrm{CH}$ qui- $\left.\mathrm{C}_{6} \mathrm{H}_{4}\right)$, 126.0 ( $\mathrm{IrC}$ qui- $\mathrm{C}_{6} \mathrm{H}_{4}$ indirectly assigned through $\mathrm{HMBC}$ ), 124.1 (s, $\mathrm{CH}$ qui- $\left.\mathrm{C}_{6} \mathrm{H}_{4}\right), 117.2\left(\mathrm{~s}, \mathrm{CH}\right.$ qui- $\left.\mathrm{C}_{6} \mathrm{H}_{4}\right), 20.1\left(\mathrm{~d},{ }^{2} J_{\mathrm{C}-\mathrm{P}}=30.3, \mathrm{PCH}\right)$, $19.3\left(\mathrm{~d},{ }^{3} J_{\mathrm{C}-\mathrm{P}}=1.0, \mathrm{PCHCH}_{3}\right), 20.0\left(\mathrm{~d},{ }^{3} J_{\mathrm{C}-\mathrm{P}}=2.7, \mathrm{PCHCH}_{3}\right) .{ }^{31} \mathrm{P}$ NMR $\left\{{ }^{1} \mathrm{H}\right\}\left(121.49 \mathrm{MHz}, \mathrm{CD}_{2} \mathrm{Cl}_{2}, 298 \mathrm{~K}\right):-2.5(\mathrm{~s})$.

Preparation of $\operatorname{IrCl}_{2}\left\{\boldsymbol{\kappa}^{2}-\mathrm{N}, \mathrm{C}\right.$-(qui- $\left.\left.\mathrm{C}_{6} \mathrm{H}_{4}\right)\right\}\left(\mathrm{PPh}_{3}\right)(\mathbf{1 1})$. Decaline (5 $\mathrm{mL})$ was added to a mixture of $\mathrm{PPh}_{3}(139.8 \mathrm{mg}, 0.53 \mathrm{mmol})$ and $\mathrm{IrCl}_{3}(\mathrm{THT})_{3}(300 \mathrm{mg}, 0.533 \mathrm{mmol})$. The resulting yellow suspension was refluxed for one hour and turned to an orange suspension. 2Phenylquinoline (120.3 mg, $0.533 \mathrm{mmol}$ ) was added and the resulting mixture was refluxed overnight. The resulting orange solid was separated by decantation. The solid was washed with $\mathrm{CH}_{2} \mathrm{Cl}_{2}(3 \times 5 \mathrm{~mL})$ and pentane $(2 \times 3 \mathrm{~mL})$. Yield: $303 \mathrm{mg}(78 \%)$. Anal. Calcd. for $\mathrm{C}_{33} \mathrm{H}_{25} \mathrm{Cl}_{2} \mathrm{IrNP}$ : C, 54.32; H, 3.45; N, 1.92. Found: C, 53.94; H, 3.60; $\mathrm{N}, 2.15 .{ }^{1} \mathrm{H}$ NMR $\left(500 \mathrm{MHz}, \mathrm{CD}_{2} \mathrm{Cl}_{2}, 298 \mathrm{~K}\right) \delta 8.17-8.13(\mathrm{~m}, 1 \mathrm{H}$,
$\mathrm{CH}$ qui- $\left.\mathrm{C}_{6} \mathrm{H}_{4}\right), 7.98-7.93\left(\mathrm{~m}, 1 \mathrm{H}, \mathrm{CH}\right.$ qui- $\left.\mathrm{C}_{6} \mathrm{H}_{4}\right), 7.79-7.75(\mathrm{~m}, 1 \mathrm{H}$, $\mathrm{CH}$ qui- $\left.\mathrm{C}_{6} \mathrm{H}_{4}\right), 7.65-7.59\left(\mathrm{~m}, 1 \mathrm{H}, \mathrm{CH}\right.$ qui- $\left.\mathrm{C}_{6} \mathrm{H}_{4}\right), 7.58-7.52(\mathrm{~m}, 2 \mathrm{H}$, $\mathrm{CH}$ qui- $\left.\mathrm{C}_{6} \mathrm{H}_{4}\right), 7.42-7.38\left(\mathrm{~m}, 1 \mathrm{H}, \mathrm{CH}\right.$ qui- $\left.\mathrm{C}_{6} \mathrm{H}_{4}\right), 7.38-7.31(\mathrm{~m}, 3 \mathrm{H}$, $\mathrm{CH} \mathrm{PPh}$ ), 7.30-7.22 (m, 6H, CH PPh $)$, 7.20-7.14 (m, 6H, CH PPh 3 , 7.10-7.04 (m, $1 \mathrm{H}, \mathrm{CH}$ qui- $\left.\mathrm{C}_{6} \mathrm{H}_{4}\right), 6.95-6.89\left(\mathrm{~m}, 1 \mathrm{H}, \mathrm{CH}\right.$ qui- $\left.\mathrm{C}_{6} \mathrm{H}_{4}\right)$ ${ }^{13} \mathrm{C}\left\{{ }^{1} \mathrm{H}\right\}+\mathrm{HMBC}+\mathrm{HSQC}$ NMR $\left(126 \mathrm{MHz}, \mathrm{CD}_{2} \mathrm{Cl}_{2}, 298 \mathrm{~K}\right) \delta 165.9$ (s, Cq qui- $\left.\mathrm{C}_{6} \mathrm{H}_{4}\right), 147.8$ (s, Cq qui- $\left.\mathrm{C}_{6} \mathrm{H}_{4}\right), 143.7$ (s, Cq qui- $\left.\mathrm{C}_{6} \mathrm{H}_{4}\right)$, $138.8\left(\mathrm{~s}, \mathrm{CH}\right.$ qui- $\left.\mathrm{C}_{6} \mathrm{H}_{4}\right), 138.5\left(\mathrm{~s}, \mathrm{CH}\right.$ qui- $\left.\mathrm{C}_{6} \mathrm{H}_{4}\right), 134.2\left(\mathrm{~d},{ }^{3} J_{\mathrm{H}-\mathrm{P}}=9.3\right.$ $\left.\mathrm{CH} \mathrm{PPh}_{3}\right), 131.5\left(\mathrm{~s}, \mathrm{CH}\right.$ qui- $\left.\mathrm{C}_{6} \mathrm{H}_{4}\right), 131.2\left(\mathrm{~d},{ }^{3} \mathrm{~J}_{\mathrm{H}-\mathrm{P}}=2.2 \mathrm{CH} \mathrm{PPh}_{3}\right)$, $130.5\left(\mathrm{~s}, \mathrm{CH}\right.$ qui- $\left.\mathrm{C}_{6} \mathrm{H}_{4}\right), 129.0\left(\mathrm{~s}, \mathrm{CH}\right.$ qui- $\left.\mathrm{C}_{6} \mathrm{H}_{4}\right), 128.6\left(\mathrm{~d},{ }^{3} \mathrm{~J}_{\mathrm{H}-\mathrm{P}}=10.7\right.$ $\left.\mathrm{CH} \mathrm{PPh}_{3}\right), 128.1\left(\mathrm{~d},{ }^{1} J_{\mathrm{H}-\mathrm{P}}=21.4, \mathrm{C}_{\mathrm{q}} \mathrm{PPh}_{3}\right), 128.00\left(\mathrm{~s}, \mathrm{CH}\right.$ qui- $\left.\mathrm{C}_{6} \mathrm{H}_{4}\right)$ $127.5\left(\mathrm{~s}, \mathrm{CH}\right.$ qui- $\left.\mathrm{C}_{6} \mathrm{H}_{4}\right), 126.0\left(\mathrm{~s}, \mathrm{CH}\right.$ qui- $\left.\mathrm{C}_{6} \mathrm{H}_{4}\right), 125.3(\mathrm{~s}, \mathrm{CH}$ qui$\left.\mathrm{C}_{6} \mathrm{H}_{4}\right), 124.4$ (s, CH qui- $\left.\mathrm{C}_{6} \mathrm{H}_{4}\right), 124.0\left(\mathrm{~d},{ }^{2} J_{\mathrm{H}-\mathrm{P}}=7.7, \operatorname{IrC}\right.$ qui- $\left.\mathrm{C}_{6} \mathrm{H}_{4}\right)$, 117.3 (s, CH qui- $\left.\mathrm{C}_{6} \mathrm{H}_{4}\right) .{ }^{31} \mathrm{P}$ NMR $\left\{{ }^{1} \mathrm{H}\right\}\left(121.49 \mathrm{MHz}, \mathrm{CD}_{2} \mathrm{Cl}_{2}, 298\right.$ $\mathrm{K}):-11.1(\mathrm{~s})$.

Preparation of $\operatorname{IrCl}\left\{\kappa^{2}-N, C-\left(q u i-\mathrm{C}_{6} \mathbf{H}_{4}\right)\right\}(\operatorname{acac})\left(\mathrm{P}^{i} \mathrm{Pr}_{3}\right) \quad$ (12). A $\mathrm{KOH}$ solution in $\mathrm{MeOH}(2.6 \mathrm{~mL}, 0.254 \mathrm{M})$ was added to acetylacetone $(69.1 \mu \mathrm{L}, 0.67 \mathrm{mmol})$. The solution was stirred for 10 minutes and then it was added to an orange suspension of compound 10 (241.2 mg, $0.337 \mathrm{mmol})$ in THF $(10 \mathrm{~mL})$. The solution was stirred overnight at r.t. and an orange solid precipitated. The resulting orange solid was decantated and washed with $\mathrm{MeOH}(3 \times 3 \mathrm{~mL})$. Yield: 115 mg (43\%). Anal. Calcd. for $\mathrm{C}_{29} \mathrm{H}_{38} \mathrm{ClIrNO}_{2} \mathrm{P}: \mathrm{C}, 50.39 ; \mathrm{H}, 5.54 ; \mathrm{N}$, 2.03. Found: C, 50.33; H, 5.21; N, 1.77. ${ }^{1} \mathrm{H}$ NMR $(300.13 \mathrm{MHz}$, $\left.\mathrm{CD}_{2} \mathrm{Cl}_{2}, 298 \mathrm{~K}\right) \delta 9.04-8.91\left(\mathrm{~m}, 1 \mathrm{H}, \mathrm{CH}\right.$ qui- $\left.\mathrm{C}_{6} \mathrm{H}_{4}\right), 8.30-8.19(\mathrm{~m}, 1 \mathrm{H}$, $\mathrm{CH}$ qui- $\left.\mathrm{C}_{6} \mathrm{H}_{4}\right), 8.17-8.08\left(\mathrm{~m}, 1 \mathrm{H}, \mathrm{CH}\right.$ qui- $\left.\mathrm{C}_{6} \mathrm{H}_{4}\right), 8.07-7.97(\mathrm{~m}, 1 \mathrm{H}$, $\mathrm{CH}$ qui- $\left.\mathrm{C}_{6} \mathrm{H}_{4}\right), 7.88-7.75\left(\mathrm{~m}, 2 \mathrm{H}, \mathrm{CH}\right.$ qui- $\left.\mathrm{C}_{6} \mathrm{H}_{4}\right), 7.73-7.62(\mathrm{~m}, 1 \mathrm{H}$, $\mathrm{CH}$ qui- $\left.\mathrm{C}_{6} \mathrm{H}_{4}\right), 7.61-7.51\left(\mathrm{~m}, 1 \mathrm{H}, \mathrm{CH}\right.$ qui- $\left.\mathrm{C}_{6} \mathrm{H}_{4}\right), 7.21-7.07(\mathrm{~m}, 2 \mathrm{H}$, $\mathrm{CH}$ qui- $\left.\mathrm{C}_{6} \mathrm{H}_{4}\right), 5.09$ (s, $1 \mathrm{H}, \mathrm{CH}$ acac), 2.65-2.42 (m, 3H, PCH), 2.08 and 1.42 (both s, $3 \mathrm{H}$ each, $\left.\mathrm{CH}_{3} \mathrm{acac}\right), 1.11\left(\mathrm{dd},{ }^{3} J_{\mathrm{H}-\mathrm{P}}=13.0,{ }^{3} J_{\mathrm{H}-\mathrm{H}}=\right.$ $\left.7.2,9 \mathrm{H}, \mathrm{PCHCH}_{3}\right), 0.97\left(\mathrm{dd},{ }^{3} J_{\mathrm{H}-\mathrm{P}}=13.1,{ }^{3} J_{\mathrm{H}-\mathrm{H}}=7.2,9 \mathrm{H}, \mathrm{PCHCH}{ }_{3}\right)$. ${ }^{13} \mathrm{C}\left\{{ }^{1} \mathrm{H}\right\}+\mathrm{HMBC}+\mathrm{HSQC}$ NMR $\left(75.47 \mathrm{MHz}, \mathrm{CD}_{2} \mathrm{Cl}_{2}, 298 \mathrm{~K}\right) \delta$ $184.7\left(\mathrm{~d},{ }^{3} J_{\mathrm{H}-\mathrm{P}}=1.5, \mathrm{Cq}\right.$ acac), 184.5 (s, Cq acac), 150.2 (s, Cq qui$\left.\mathrm{C}_{6} \mathrm{H}_{4}\right), 148.7$ (s, Cq qui- $\left.\mathrm{C}_{6} \mathrm{H}_{4}\right), 146.0\left(\mathrm{~d},{ }^{2} J_{\mathrm{C}-\mathrm{P}}=7.8, \mathrm{Cq} \mathrm{IrC}\right.$ qui- $\left.\mathrm{C}_{6} \mathrm{H}_{4}\right)$, $139.2\left(\mathrm{~s}, \mathrm{CH}\right.$ qui- $\left.\mathrm{C}_{6} \mathrm{H}_{4}\right), 138.9\left(\mathrm{~s}, \mathrm{CH}\right.$ qui- $\left.\mathrm{C}_{6} \mathrm{H}_{4}\right), 130.9$ (s, $\mathrm{CH}$ qui$\left.\mathrm{C}_{6} \mathrm{H}_{4}\right), 129.2$ (s, CH qui- $\left.\mathrm{C}_{6} \mathrm{H}_{4}\right), 128.9\left(\mathrm{~s}, \mathrm{CH}\right.$ qui- $\left.\mathrm{C}_{6} \mathrm{H}_{4}\right), 127.8$ (d, Cq qui- $\left.\mathrm{C}_{6} \mathrm{H}_{4}\right), 127.4\left(\mathrm{~s}, \mathrm{CH}\right.$ qui- $\left.\mathrm{C}_{6} \mathrm{H}_{4}\right), 126.8\left(\mathrm{~s}, \mathrm{CH}\right.$ qui- $\left.\mathrm{C}_{6} \mathrm{H}_{4}\right), 126.4(\mathrm{~s}$, $\mathrm{CH}$ qui- $\left.\mathrm{C}_{6} \mathrm{H}_{4}\right), 122.9\left(\mathrm{~s}, \mathrm{CH}\right.$ qui- $\left.\mathrm{C}_{6} \mathrm{H}_{4}\right), 117.9\left(\mathrm{~s}, \mathrm{CH}\right.$ qui- $\left.\mathrm{C}_{6} \mathrm{H}_{4}\right), 100.1$ (s, $\mathrm{CH}$ acac), $28.5\left(\mathrm{~s}, \mathrm{CH}_{3} \mathrm{acac}\right), 28.1\left(\mathrm{~d},{ }^{4} J_{\mathrm{C}-\mathrm{P}}=6.2, \mathrm{CH}_{3} \mathrm{acac}\right), 26.0$ $\left(\mathrm{d},{ }^{2} J_{\mathrm{C}-\mathrm{P}}=30.5, \mathrm{PCH}\right), 20.5\left(\mathrm{~d},{ }^{3} J_{\mathrm{C}-\mathrm{P}}=2.8, \mathrm{PCHCH}{ }_{3}\right), 20.0\left(\mathrm{~d},{ }^{3} J_{\mathrm{C}-\mathrm{P}}=\right.$ 1.4, $\left.\mathrm{PCHCH}_{3}\right) .{ }^{31} \mathrm{P}$ NMR $\left\{{ }^{1} \mathrm{H}\right\}\left(121.49 \mathrm{MHz}, \mathrm{CD}_{2} \mathrm{Cl}_{2}, 298 \mathrm{~K}\right):-16.3$ (s).

Preparation of $\operatorname{IrCl}\left\{\kappa^{2}-N, C\right.$ - $\left.\left(q u i-\mathrm{C}_{6} \mathrm{H}_{4}\right)\right\}($ acac $)\left(\mathrm{PPh}_{3}\right)$ (13). A $\mathrm{KOH}$ solution in $\mathrm{MeOH}(3.0 \mathrm{~mL}, 0.254 \mathrm{M})$ was added to acetylacetone $(79 \mu \mathrm{L}, 0.77 \mathrm{mmol})$. The solution was stirred for 10 minutes and then it was added to an orange suspension of compound 11 (300 $\mathrm{mg}, 0.439 \mathrm{mmol})$ in THF $(15 \mathrm{~mL})$. The solution was stirred overnight at r.t. and a yellow solid precipitated. The resulting yellow solid was decantated and washed with $\mathrm{MeOH}(3 \times 3 \mathrm{~mL})$. Yield: $225.3 \mathrm{mg}(65$ \%). Anal. Calcd. for $\mathrm{C}_{38} \mathrm{H}_{32} \mathrm{ClIINO}_{2} \mathrm{P}: \mathrm{C}, 57.53 ; \mathrm{H}, 4.07 ; \mathrm{N}, 1.77$. Found: C, 57.28; $\mathrm{H}, 4.01 ; \mathrm{N}, 1.82 .{ }^{1} \mathrm{H}$ NMR $\left(300.13 \mathrm{MHz}, \mathrm{CD}_{2} \mathrm{Cl}_{2}\right.$, $298 \mathrm{~K}) \delta 8.47-8.40\left(\mathrm{~m}, 1 \mathrm{H}, \mathrm{CH}\right.$ qui- $\left.\mathrm{C}_{6} \mathrm{H}_{4}\right), 8.00-7.89(\mathrm{~m}, 2 \mathrm{H}, \mathrm{CH}$ qui- $\left.\mathrm{C}_{6} \mathrm{H}_{4}\right), 7.80-7.76\left(\mathrm{~m}, 1 \mathrm{H}, \mathrm{CH}\right.$ qui- $\left.\mathrm{C}_{6} \mathrm{H}_{4}\right), 7.59-7.48(\mathrm{~m}, 8 \mathrm{H}, 2 \mathrm{CH}$ qui- $\left.\mathrm{C}_{6} \mathrm{H}_{4} 6 \mathrm{CH} \mathrm{PPh}\right), 7.36-7.26\left(\mathrm{~m}, 2 \mathrm{H}, \mathrm{CH}\right.$ qui- $\left.\mathrm{C}_{6} \mathrm{H}_{4}\right), 7.23-7.14(\mathrm{~m}$, $3 \mathrm{H}, 3 \mathrm{CH} \mathrm{PPh}$ ), 7.13-7.04 (m, 7H, CH qui- $\left.\mathrm{C}_{6} \mathrm{H}_{4} \mathrm{CH} \mathrm{PPh}_{3}\right), 6.87-6.79$ $\left(\mathrm{m}, 1 \mathrm{H}\right.$, qui- $\left.\mathrm{C}_{6} \mathrm{H}_{4}\right), 5.12(\mathrm{~s}, 1 \mathrm{H}, \mathrm{CH}$ acac), 2.11 and 1.47 (both s, $3 \mathrm{H}$ each, $\mathrm{CH}_{3}$ acac). ${ }^{13} \mathrm{C}\left\{{ }^{1} \mathrm{H}\right\}+$ HMBC + HSQC NMR (75.47 MHz, $\left.\mathrm{CD}_{2} \mathrm{Cl}_{2}, 298 \mathrm{~K}\right) \delta 185.0\left(\mathrm{~d},{ }^{3} J_{\mathrm{C}-\mathrm{P}}=1.6, \mathrm{Cq} \mathrm{acac}\right), 185.0$ (s, Cq acac), $170.4\left(\mathrm{~s}, \mathrm{Cq}\right.$ qui- $\left.\mathrm{C}_{6} \mathrm{H}_{4}\right), 148.3\left(\mathrm{~s}, \mathrm{Cq}\right.$ qui- $\left.\mathrm{C}_{6} \mathrm{H}_{4}\right), 148.1$ (s, Cq qui$\left.\mathrm{C}_{6} \mathrm{H}_{4}\right), 144.2\left(\mathrm{~d},{ }^{2} J_{\mathrm{C}-\mathrm{P}}=9.6, \mathrm{Cq} \operatorname{IrC}\right.$ qui- $\left.\mathrm{C}_{6} \mathrm{H}_{4}\right), 139.2(\mathrm{~s}, \mathrm{CH}$ qui$\left.\mathrm{C}_{6} \mathrm{H}_{4}\right), 138.9$ (s, CH qui- $\left.\mathrm{C}_{6} \mathrm{H}_{4}\right), 134.7\left(\mathrm{~d},{ }^{3} J_{\mathrm{C}-\mathrm{P}}=9.2, \mathrm{CH} \mathrm{PPh}_{3}\right), 131.4$ $\left(\mathrm{d},{ }^{1} J_{\mathrm{C}-\mathrm{P}}=59.6, \mathrm{Cq} \mathrm{PPh}_{3}\right), 130.4\left(\mathrm{~s}, \mathrm{CH}\right.$ qui-C $\left.{ }_{6} \mathrm{H}_{4}\right), 130.2\left(\mathrm{~d},{ }^{5} J_{\mathrm{C}-\mathrm{P}}=\right.$ 2.6, $\mathrm{CH} \mathrm{PPh}$ ), $129.0\left(\mathrm{~s}, \mathrm{CH}\right.$ qui- $\left.\mathrm{C}_{6} \mathrm{H}_{4}\right), 128.3\left(\mathrm{~s}, \mathrm{CH}\right.$ qui- $\left.\mathrm{C}_{6} \mathrm{H}_{4}\right), 127.6$ $\left(\mathrm{d},{ }^{4} J_{\mathrm{C}-\mathrm{P}}=10.5, \mathrm{CH} \mathrm{Ph}\right), 127.2\left(\mathrm{~s}, \mathrm{Cq}\right.$ qui-C $\left.\mathrm{C}_{6} \mathrm{H}_{4}\right), 126.8(\mathrm{~s}, \mathrm{CH}$ qui$\left.\mathrm{C}_{6} \mathrm{H}_{4}\right), 126.4$ (s, $\mathrm{CH}$ qui- $\left.\mathrm{C}_{6} \mathrm{H}_{4}\right), 125.8\left(\mathrm{~s}, \mathrm{CH}\right.$ qui- $\left.\mathrm{C}_{6} \mathrm{H}_{4}\right), 123.0(\mathrm{~s}, \mathrm{CH}$ qui- $\left.\mathrm{C}_{6} \mathrm{H}_{4}\right), 117.7$ (s, $\mathrm{CH}$ qui- $\left.\mathrm{C}_{6} \mathrm{H}_{4}\right) 100.5\left(\mathrm{~s}, \mathrm{CH}\right.$ acac), $28.9\left(\mathrm{~s}, \mathrm{CH}_{3}\right.$ acac), $28.0\left(\mathrm{~d},{ }^{4} J_{\mathrm{C}-\mathrm{P}}=6.8 \mathrm{CH}_{3}\right.$ acac$) .{ }^{31} \mathrm{P}$ NMR $\left\{{ }^{1} \mathrm{H}\right\}(121.49 \mathrm{MHz}$, $\left.\mathrm{CD}_{2} \mathrm{Cl}_{2}, 298 \mathrm{~K}\right):-28.0$ (s).

Structural Analysis of Complexes 2, 3, 4, 5, 7, 10 and 12. X-ray data were collected for the complexes on a Bruker Smart APEX CCD $(\mathbf{2}, \mathbf{3}, \mathbf{5}$ and 7) or APEX CCD DUO (4, 10 and 12) diffractometers equipped with a normal focus, $2.4 \mathrm{~kW}$ sealed tube source (Mo radia- 
tion, $\lambda=0.71073 \AA$ ) operating at $50 \mathrm{kV}$ and $40 \mathrm{~mA}(\mathbf{1 0}, \mathbf{1 2})$ or $30 \mathrm{~mA}$ $(2,3,4,5$ and 7$)$. Data were collected over the complete sphere. Each frame exposure time was $10 \mathrm{~s}, 20 \mathrm{~s} \mathrm{(10)}$ or $30 \mathrm{~s} \mathrm{(12)} \mathrm{covering} 0.3^{\circ}$ in $\omega$. Data were corrected for absorption by using a multiscan method applied with the SADABS program. ${ }^{30}$ The structures were solved by Patterson or direct methods and refined by full-matrix least squares on $\mathrm{F}^{2}$ with SHELXL97, ${ }^{31}$ including isotropic and subsequently anisotropic displacement parameters. The hydrogen atoms were observed in the least Fourier Maps or calculated, and refined freely or using a restricted riding model. The hydrogen atoms bonded to metals were observed in the last cycles of refinement but refined too close to metals, so a restricted refinement model was used for all of them (d(Ir-H=1.59(1) $\AA$ ). In 5 the $\mathrm{BF}_{4}$ anion was observed disordered and refined with two moieties with restrained geometries, complementary occupancy factors and isotropic displacement parameters.

Crystal data for 2: $\mathrm{C}_{33} \mathrm{H}_{54} \mathrm{IrNP}_{2}, \mathrm{M}_{\mathrm{W}} 718.91$, red, irregular block $(0.18 \times 0.09 \times 0.05)$, triclinic, space group P-1, $a: 10.1874(12) \AA, b$ : 10.8208(12) $\AA, c: 14.5916(17) \AA, a: 90.186(2)^{\circ}, \beta: 98.797(2)^{\circ}, \gamma:$ 91.385(2) ${ }^{\circ}, V=1589.1(3) \AA^{3}, Z=2, Z^{\prime}=1, \mathrm{D}_{\text {calc }}: 1.502 \mathrm{~g} \mathrm{~cm}^{-3}$, $\mathrm{F}(000): 732, \mathrm{~T}=100(2) \mathrm{K}, \mu 4.324 \mathrm{~mm}^{-1} .22474$ measured reflections (20: $3-57^{\circ}$, $\omega$ scans $\left.0.3^{\circ}\right), 8098$ unique $\left(\mathrm{R}_{\mathrm{int}}=0.0271\right)$; $\min . / \mathrm{max}$. transm. Factors $0.601 / 0.862$. Final agreement factors were $\mathrm{R}^{1}=$ 0.0228 (7461 observed reflections, $\mathrm{I}>2 \sigma(\mathrm{I})$ ) and $\mathrm{wR}^{2}=0.0595$; data/restraints/parameters 8098/2/352; GoF $=0.944$. Largest peak and hole 3.733 (close to iridium atoms) and $-0.619 \mathrm{e} / \AA^{3}$.

Crystal data for 3: $\mathrm{C}_{33} \mathrm{H}_{53} \mathrm{IrNP}_{2}, \mathrm{BF}_{4}, \mathrm{M}_{\mathrm{W}}$ 804.71, red, irregular block $(0.20 \times 0.10 \times 0.08)$, trigonal, space group $\mathrm{P}_{2}, a$ : $10.7169(11)$ $\AA, b: 10.7169(11) \AA, c: 25.760(3) \AA, V=2562.2(5) \AA^{3}, Z=3, Z^{\prime}=1$, $\mathrm{D}_{\text {calc }}: 1.565 \mathrm{~g} \mathrm{~cm}^{-3}, \mathrm{~F}(000): 1218, \mathrm{~T}=100(2) \mathrm{K}, \mu 4.047 \mathrm{~mm}^{-1} .30039$ measured reflections $\left(2 \theta: 3-58^{\circ}, \omega\right.$ scans $\left.0.3^{\circ}\right), 8901$ unique $\left(\mathrm{R}_{\text {int }}=\right.$ 0.0330 ); min./max. transm. Factors $0.714 / 0.746$. Final agreement factors were $\mathrm{R}^{1}=0.0222(8754$ observed reflections, $\mathrm{I}>2 \sigma(\mathrm{I}))$ and $\mathrm{wR}^{2}=0.0459$; Flack parameter $=0.00$; data/restraints/parameters 8901/2/397; GoF $=1.015$. Largest peak and hole 1.120 (close to iridium atom) and $-0.362 \mathrm{e} / \AA^{3}$.

Crystal data for 4: $\mathrm{C}_{29} \mathrm{H}_{39} \mathrm{IrNO}_{2} \mathrm{P}, \mathrm{M}_{\mathrm{W}}$ 656.78, yellow, irregular block $(0.29 \times 0.09 \times 0.07)$, monoclinic, space group $\mathrm{P}_{1} / \mathrm{n}, a$ : 8.5813(5) $\AA, b: 16.2812(9) \AA, c: 19.0759(10) \AA, \beta: 96.1550(10)^{\circ}, V=$ $2649.8(3) \AA^{3}, Z=4, Z^{\prime}=1, \mathrm{D}_{\text {calc }}: 1.646 \mathrm{~g} \mathrm{~cm}^{-3}, \mathrm{~F}(000): 1312, \mathrm{~T}=$ $100(2) \mathrm{K}, \mu 5.125 \mathrm{~mm}^{-1} .23035$ measured reflections $\left(2 \theta: 3-57^{\circ}, \omega\right.$ scans $\left.0.3^{\circ}\right), 6351$ unique $\left(\mathrm{R}_{\text {int }}=0.0287\right) ; \mathrm{min} . / \mathrm{max}$. transm. Factors $0.580 / 0.862$. Final agreement factors were $\mathrm{R}^{1}=0.0240(5598 \mathrm{ob}-$ served reflections, $\mathrm{I}>2 \sigma(\mathrm{I}))$ and $\mathrm{wR}^{2}=0.0567$; data/restraints/parameters 6351/1/321; GoF $=1.040$. Largest peak and hole 1.481 (close to iridium atoms) and $-1.642 \mathrm{e} / \AA^{3}$.

Crystal data for 5: $\mathrm{C}_{41} \mathrm{H}_{59} \mathrm{IrNP}_{2}, \mathrm{BF}_{4}, 2 \mathrm{C}_{3} \mathrm{H}_{6} \mathrm{O} \mathrm{M}_{\mathrm{W}} 1023.00$, orange, irregular block $(0.19 \times 0.13 \times 0.09)$, triclinic, space group P-1, $a: 11.2358(11) \AA, b: 11.6571(12) \AA, c: 19.137(3) \AA, a: 102.171(2)^{\circ}$, $\beta: 98.769(2)^{\circ}, \gamma: 104.3400(10)^{\circ}, V=2317.8(5) \AA^{3}, Z=2, Z^{\prime}=1, \mathrm{D}_{\text {calc }}$ : $1.466 \mathrm{~g} \mathrm{~cm}^{-3}, \mathrm{~F}(000): 1048, \mathrm{~T}=100(2) \mathrm{K}, \mu 3.003 \mathrm{~mm}^{-1} .37621$ measured reflections $\left(2 \theta: 3-57^{\circ}\right.$, $\omega$ scans $\left.0.3^{\circ}\right), 11934$ unique $\left(R_{\text {int }}=\right.$ 0.0272); min./max. transm. Factors $0.715 / 0.862$. Final agreement factors were $\mathrm{R}^{1}=0.0241(11017$ observed reflections, $\mathrm{I}>2 \sigma(\mathrm{I}))$ and $\mathrm{wR}^{2}=0.0586 ;$ data/restraints/parameters $11934 / 20 / 536 ; \mathrm{GoF}=1.043$. Largest peak and hole 1.523 (close to iridium atoms) and $-1.604 \mathrm{e} /$ $\AA^{3}$.

Crystal data for 7: $\mathrm{C}_{37} \mathrm{H}_{45} \mathrm{IrNO}_{2} \mathrm{P}, \mathrm{M}_{\mathrm{W}} 758.91$, orange, irregular block $(0.17 \times 0.13 \times 0.13)$, orthorhombic, space group $\mathrm{P} 22_{2} 2_{2}, a$ : 18.3509(19) $\AA, b: 10.8406(11) \AA, c: 16.2855(16) \AA, V=3239.8(6)$ $\AA^{3}, Z=4, Z^{\prime}=1, \mathrm{D}_{\text {calc }}: 1.556 \mathrm{~g} \mathrm{~cm}^{-3}, \mathrm{~F}(000): 1528, \mathrm{~T}=100(2) \mathrm{K}, \mu$ $4.204 \mathrm{~mm}^{-1} .50581$ measured reflections $\left(2 \theta: 3-57^{\circ}, \omega\right.$ scans $\left.0.3^{\circ}\right)$, 8601 unique $\left(\mathrm{R}_{\text {int }}=0.0368\right)$; min./max. transm. Factors $0.744 / 0.862$. Final agreement factors were $\mathrm{R}^{1}=0.0238$ (7804 observed reflections, $\mathrm{I}>2 \sigma(\mathrm{I}))$ and $\mathrm{wR}^{2}=0.0446$; Flack parameter $=-0.001(4)$; data/restraints/parameters 8601/1/386; $\mathrm{GoF}=1.013$. Largest peak and hole 1.821 (close to iridium atoms) and $-0.451 \mathrm{e} / \AA^{3}$.

Crystal data for 10: $\mathrm{C}_{24} \mathrm{H}_{31} \mathrm{Cl}_{2} \mathrm{IrNP}, \mathrm{M}_{\mathrm{W}} 627.57$, orange, irregular block $(0.19 \times 0.17 \times 0.13)$, monoclinic, space group $\mathrm{P} 2{ }_{1} / \mathrm{c}, a$ : 18.0378(9) $\AA, b: 9.5865(5) \AA, c: 14.4984(7) \AA, \beta: 108.7260(10)^{\circ}, V=$ 2374.3(2) $\AA^{3}, Z=4, Z^{\prime}=1, \mathrm{D}_{\text {calc }}: 1.756 \mathrm{~g} \mathrm{~cm}^{-3}, \mathrm{~F}(000): 1232, \mathrm{~T}=$ $100(2) \mathrm{K}, \mu 5.927 \mathrm{~mm}^{-1} .28083$ measured reflections $\left(2 \theta: 3-57^{\circ}, \omega\right.$ scans $\left.0.3^{\circ}\right), 5718$ unique $\left(\mathrm{R}_{\text {int }}=0.0345\right) ; \mathrm{min} . / \mathrm{max}$. transm. Factors
$0.670 / 0.862$. Final agreement factors were $\mathrm{R}^{1}=0.0234$ (5026 observed reflections, $\mathrm{I}>2 \sigma(\mathrm{I}))$ and $\mathrm{wR}^{2}=0.0506$; data/restraints/parameters 5718/0/268; GoF $=1.034$. Largest peak and hole 1.444 (close to iridium atoms) and $-0.856 \mathrm{e} / \AA^{3}$.

Crystal data for 12: $\mathrm{C}_{29} \mathrm{H}_{38} \mathrm{ClIrNO}_{2} \mathrm{P}, \mathrm{M}_{\mathrm{W}} 691.22$, orange, irregular block ( $0.18 \times 0.13 \times 0.12)$, orthorhombic, space group $\mathrm{P} 2{ }_{1} 2_{1} 2_{1}$, $a$ : 9.4611(6) $\AA, b: 15.0151(10) \AA, c: 19.4449(13) \AA, V=2762.3(3) \AA^{3}, Z$ $=4, Z^{\prime}=1, \mathrm{D}_{\text {calc }}: 1.662 \mathrm{~g} \mathrm{~cm}^{-3}, \mathrm{~F}(000): 1376, \mathrm{~T}=100(2) \mathrm{K}, \mu 5.015$ $\mathrm{mm}^{-1} .33776$ measured reflections $\left(2 \theta: 3-57^{\circ}, \omega\right.$ scans $\left.0.3^{\circ}\right), 6691$ unique $\left(\mathrm{R}_{\text {int }}=0.0438\right)$; min./max. transm. Factors $0.699 / 0.862$. Final agreement factors were $\mathrm{R}^{1}=0.0227$ (6449 observed reflections, I > $2 \sigma(\mathrm{I}))$ and $\mathrm{wR}^{2}=0.0498$; Flack parameter $=0.000(5)$; data/restraints/parameters 6691/0/325; $\mathrm{GoF}=1.043$. Largest peak and hole 1.226 (close to iridium atoms) and $-0.779 \mathrm{e} / \AA^{3}$.

Computational details: All calculations were performed at the DFT level using the B3LYP functional ${ }^{32}$ supplemented with the Grimme's dispersion correction D3 ${ }^{33}$ as implemented in Gaussian09. ${ }^{34} \mathrm{Ir}$ atom was described by means of an effective core potential SDD for the inner electrons ${ }^{35}$ and its associated double- $\zeta$ basis set for the outer ones, complemented with a set of f-polarization functions. ${ }^{36}$ The 6-31G** basis set was used for the $\mathrm{H}, \mathrm{C}, \mathrm{N}$ and $\mathrm{P}$ atoms. ${ }^{37}$ The singlet $\left(\mathrm{S}_{0}\right)$ and lowest triplet excited geometries $\left(\mathrm{T}_{1}\right)$ were computed with the B3LYP and unrestricted B3LYP (UB3LYP) functionals, respectively. Full geometry optimizations without symmetry constraints were carried out. Following the optimization of these states, the vibrational frequencies were calculated and the results showed that all optimized structures are minima on the potential energy surface. All geometries were fully optimized in THF $(\varepsilon=7.4257)$ solvent using the continuum SMD model. ${ }^{38}$ We also performed TD-DFT calculations at the same level of theory calculating the lowest 50 singletsinglet excitations at the ground state $S_{0}$ and the lowest 5 singletsinglet and 5 singlet-triplet excitations at the lowest excited triplet $\mathrm{T}_{1}$ optimized geometries. It has to be noticed that the singlet-triplet excitations are set to zero due to the neglect of spin-orbit coupling in the TDDFT calculations as implemented in G09. The UV/vis absorption spectra were obtained by using the GaussSum 3 software. ${ }^{39}$ The methodology for the optimization and fully refinement of the ${ }^{3} \mathrm{MC}$ states was performed following the method described previously. ${ }^{40}$ The ${ }^{3} \mathrm{MC}$ minima shows a tetragonal distortion by elongation along the N-Ir-H (4) or N-Ir-Cl (12) axis, or decoordination of one oxygen atom of the acac ligand to form a trigonal bipyramid structure in 7 and 8 .

\section{ASSOCIATED CONTENT}

\section{Supporting Information}

The Supporting Information is available free of charge on the ACS Publications website.

${ }^{1} \mathrm{H}$ NMR, ${ }^{13} \mathrm{C}\left\{{ }^{1} \mathrm{H}\right\}$ APT and ${ }^{31} \mathrm{P}\left\{{ }^{1} \mathrm{H}\right\}$ NMR spectra used in the characterization of all the complexes. UV/Vis experimental and computed spectra, normalized emission and excitation spectra, and orbital composition for complexes 4, 7, 8, 12 and 13 (PDF). Crystallographic data for compounds $2,3,4,5,7,10$, and 12 (CIF).

Cartesian coordinates of the compounds 4, 7, 8, 12 and 13 (XYZ).

\section{AUTHOR INFORMATION}

\section{Corresponding Author}

*E-mail for M. A. E.: maester@unizar.es *

\section{Author Contribution}

The manuscript was written through contributions of all authors. All authors have given approval to the final version of the manuscript.

Notes

The authors declare no competing financial interest.

\section{ACKNOWLEDGMENT}


Financial support from the MINECO of Spain (Projects CTQ2014-52799-P), DGA (E35), FEDER and the European Social Fund is acknowledged. EO thankfully acknowledges the resources from the supercomputer "Memento", technical expertise and assistance provided by BIFI-ZCAM (Universidad de Zaragoza).

\section{REFERENCES}

(1) (a) Lowry, M. S.; Bernhard, S. Chem. Eur. J. 2006, 12, 79707977. (b) Flamigni, L.; Barbieri, A.; Sabatini, C.; Ventura, B.; Barigelletti, F. Top Curr. Chem. 2007, 281, 143-203. (c) Williams, J. A. G.; Wilkinson, A. J.; Whittle, V. L. Dalton Trans. 2008, 2081-2099. (d) Wong, W. Y.; Ho, C. L. Coord. Chem. Rev. 2009, 253, 17091758. (e) You, Y.; Park, S. Y. Dalton Trans. 2009, 1267-1282. (f) Liu, Z.; Bian, Z.; Huang, C. Top Curr. Chem. 2010, 28, 113-142. (g) Powell, B. J. Coord. Chem. Rev. 2015, 295, 46-79. (h) Zanoni, K. P. S.; Coppo, R. L.; Amaral, R. C.; Murakami Iha, N. Y. Dalton Trans. 2015, 44, 14559-14573. (i) Kapturkiewicz, A. Anal. Bioanal. Chem. 2016, 408, 7013-7033. (j) Omae, I. Coord. Chem. Rev. 2016, 310, 154-169.

(2) Yang, X.; Xu, X.; Dang, J.-s.; Zhou, G.; Ho, C.-L.; Wong, W.Y. Inorg. Chem. 2016, 55, 1720-1727.

(3) (a) Collin, J.-P.; Dixon, I. M.; Sauvage, J.-P.; Williams, J. A. G.; Barigelletti, F.; Flamigni, L. J. Am. Chem. Soc. 1999, 121, 50095016. (b) Flamigni, L.; Collin, J.-P.; Sauvage, J.-P. Acc. Chem. Res. 2008, 41, 857-871. (c) Tinker, L. L.; Bernhard, S. Inorg. Chem. 2009, 48, 10507-10511. (d) Chen, J.-L.; Wu, Y.-H.; He, L.-H.; Wen, H.-R.; Liao, J.; Hong, R. Organometallics 2010, 29, 2882-2891.

(4) (a) Tsuchiya, K.; Yagai, S.; Kitamura, A.; Karatsu, T.; Endo, K.; Mizukami, J.; Akiyama, S.; Yabe, M. Eur. J. Inorg. Chem. 2010, 2010, 926-933. (b) Feldman, J.; Vo, G. D.; McLaren, C. D.; Gehret, T. C.; Park, K.-H.; Meth, J. S.; Marshall, W. J.; Buriak, J.; Bryman, L. M.; Dobbs, K. D.; Scholz, T. H.; Zane, S. G. Organometallics 2015, 34, 3665-3669. (c) Kando, A.; Hisamatsu, Y.; Ohwada, H.; Itoh, T.; Moromizato, S.; Kohno, M.; Aoki, S. Inorg. Chem. 2015, 54, 53425357. (d) Hisamatsu, Y.; Shibuya, A.; Suzuki, N.; Suzuki, T.; Abe, R.; Aoki, S. Bioconjugate Chem 2015, 26, 857-879.

(5) (a) Monti, F.; La Placa, M. G. I.; Armaroli, N.; Scopelliti, R.; Grätzel, M.; Nazeeruddin, M. K.; Kessler, F. Inorg. Chem. 2015, 54, 3031-3042. (b) Connell, T. U.; White, J. M.; Smith, T. A.; Donnelly, P. S. Inorg. Chem. 2016, 55, 2776-2790. (c) Ponce, J.; Aragó, J.; Vayá, I.; Magenti, J. G.; Tatay, S.; Ortí, E.; Coronado, E. Eur. J. Inorg. Chem. 2016, 2016, 1851-1859. (d) Sarma, M.; Chatterjee, T.; Bodapati, R.; Krishnakanth, K. N.; Hamad, S.; Venugopal Rao, S.; Das, S. K. Inorg. Chem. 2016, 55, 3530-3540. (e) Zhao, K.-Y.; Shan, G.-G.; Fu, Q.; Su, Z.-M. Organometallics 2016, 35, 3996-4001.

(6) (a) Ma, D.; Zhang, C.; Qiu, Y.; Duan, L. Org. Electron. 2016, 39, 16-24. (b) Suhr, K. J.; Bastatas, L. D.; Shen, Y.; Mitchell, L. A.; Frazier, G. A.; Taylor, D. W.; Slinker, J. D.; Holliday, B. J. Dalton Trans. 2016, 45, 17807-17823. (c) Zhang, F.; Li, W.; Wei, D.; Dong, X.; Li, S.; Li, Z.; Zhang, F.; Wei, X.; Wei, B.; Cao, G.; Zhai, B. Inorg. Chim. Acta. 2016, 453, 115-121.

(7) (a) Costa, R. D.; Ortí, E.; Bolink, H.; Monti, F.; Accorsi, G.; Armaroli, N. Angew. Chem., Int. Ed. Engl. 2012, 51, 8178-211; (ii) Hu, T.; He, L.; Duan, L.; Qiu, Y. J. Mater. Chem. 2012, 22, 42064215.

(8) (a) Alabau, R. G.; Eguillor, B.; Esler, J.; Esteruelas, M. A.; Oliván, M.; Oñate, E.; Tsai, J.-Y.; Xia, C. Organometallics 2014, 33, 5582-5596. (b) Duan, T.; Chang, T.-K.; Chi, Y.; Wang, J.-Y.; Chen, Z.-N.; Hung, W.-Y.; Chen, C.-H.; Lee, G.-H. Dalton Trans. 2015, 44, 14613-14624. (c) Kuei, C.-Y.; Tsai, W.-L.; Tong, B.; Jiao, M.; Lee, W.-K.; Chi, Y.; Wu, C.-C.; Liu, S.-H.; Lee, G.-H.; Chou, P.-T. Adv Mater 2016, 28, 2795-2800. (d) Umamahesh, B.; Karthikeyan, N. S.; Sathiyanarayanan, K. I.; Malicka, J. M.; Cocchi, M. J. Mater. Chem. C 2016, 4, 10053-10060.

(9) (a) Wilkinson, A. J.; Goeta, A. E.; Foster, C. E.; Williams, J. A. G. Inorg. Chem. 2004, 43, 6513-6515. (b) Wilkinson, A. J.; Puschmann, H.; Howard, J. A. K.; Foster, C. E.; Williams, J. A. G. Inorg. Chem. 2006, 45, 8685-8699. (c) Lin, J.; Chau, N.-Y.; Liao, J.L.; Wong, W.-Y.; Lu, C.-Y.; Sie, Z.-T.; Chang, C.-H.; Fox, M. A.; Low, P. J.; Lee, G.-H.; Chi, Y. Organometallics 2016, 35, 1813-1824.
(10) (a) Obara, S.; Itabashi, M.; Okuda, F.; Tamaki, S.; Tanabe, Y.; Ishii, Y.; Nozaki, K.; Haga, M.-a. Inorg. Chem. 2006, 45, 89078921. (b) Brulatti, P.; Gildea, R. J.; Howard, J. A. K.; Fattori, V.; Cocchi, M.; Williams, J. A. G. Inorg. Chem. 2012, 51, 3813-3826. (c) Gildea, L. F.; Batsanov, A. S.; Williams, J. A. G. Dalton Trans. 2013, 42, 10388-10393.

(11) (a) Stringer, B. D.; Quan, L. M.; Barnard, P. J.; Wilson, D. J. D.; Hogan, C. F. Organometallics 2014, 33, 4860-4872. (b) Kim, T.; Lee, J.; Lee, S. U.; Lee, M. H. Organometallics 2015, 34, 3455-3458. (c) Lee, Y. H.; Park, J.; Lee, J.; Lee, S. U.; Lee, M. H. J. Am. Chem. Soc. 2015, 137, 8018-8021. (d) Li, T.-Y.; Liang, X.; Zhou, L.; Wu, C.; Zhang, S.; Liu, X.; Lu, G.-Z.; Xue, L.-S.; Zheng, Y.-X.; Zuo, J.-L. Inorg. Chem. 2015, 54, 161-173. (e) Nguyen, V. H.; Khoo, R. S. H.; Yip, J. H. K. Inorg. Chem. 2015, 54, 2264-2277. (f) Radwan, Y. K.; Maity, A.; Teets, T. S. Inorg. Chem. 2015, 54, 7122-7131. (g) Zhou, Y.; Gao, H.; Wang, X.; Qi, H. Inorg. Chem. 2015, 54, 1446-1453. (h) Kumar, S.; Hisamatsu, Y.; Tamaki, Y.; Ishitani, O.; Aoki, S. Inorg. Chem. 2016, 55, 3829-3843. (i) Lee, H. J.; Ha, Y. Polym. Bull. 2016, 73, 2501-2509. (j) Shang, X.; Han, D.; Zhang, H.; Zhou, L.; Zhang, G. Eur. J. Inorg. Chem. 2016, 2016, 1541-1547. (k) Yi, S.; Kim, J.H.; Cho, Y.-J.; Lee, J.; Choi, T.-S.; Cho, D. W.; Pac, C.; Han, W.-S.; Son, H.-J.; Kang, S. O. Inorg. Chem. 2016, 55, 3324-3331. (1) Axtell, J. C.; Kirlikovali, K. O.; Djurovich, P. I.; Jung, D.; Nguyen, V. T.; Munekiyo, B.; Royappa, A. T.; Rheingold, A. L.; Spokoyny, A. M. J. Am. Chem. Soc. 2016, 138, 15758-15765.

(12) (a) Edkins, R. M.; Wriglesworth, A.; Fucke, K.; Bettington, S. L.; Beeby, A. Dalton Trans. 2011, 40, 9672-9678. (b) Baranoff, E.; Curchod, B. F. E.; Frey, J.; Scopelliti, R.; Kessler, F.; Tavernelli, I.; Rothlisberger, U.; Grätzel, M.; Nazeeruddin, M. K. Inorg. Chem. 2012, 51, 215-224. (c) Xu, X.; Yang, X.; Wu, Y.; Zhou, G.; Wu, C.; Wong, W.-Y. Chem. Asian J. 2015, 10, 252-262.

(13) (a) Shen, X.; Hu, X.-H.; Wang, F.-L.; Sun, F.; Yang, Y.-Q.; $\mathrm{Xu}, \mathrm{Y}$.; Chen, S.; Zhu, D.-R. Inorg. Chem. Commun. 2010, 13, 10961099. (b) Chen, Z.-Q.; Shen, X.; Xu, J.-X.; Zou, H.; Wang, X.; Xu, Y.; Zhu, D.-R. Inorg. Chem. Commun. 2015, 61, 152-156. (c) Shang, X.; Han, D.; Zhou, L.; Wan, N.; Zhang, G. Polyhedron 2015, 98, 196202. (d) Sanner, R. D.; Cherepy, N. J.; Young Jr, V. G. Inorg. Chim. Acta. 2016, 440, 165-171.

(14) (a) Eum, M.-S.; Chin, C. S.; Kim, S. y.; Kim, C.; Kang, S. K.; Hur, N. H.; Seo, J. H.; Kim, G. Y.; Kim, Y. K. Inorg. Chem. 2008, 47, 6289-6295. (b) Alam, P.; Karanam, M.; Roy Choudhury, A.; Rahaman Laskar, I. Dalton Trans. 2012, 41, 9276-9279.

(15) Liao, J.-L.; Chi, Y.; Sie, Z.-T.; Ku, C.-H.; Chang, C.-H.; Fox, M. A.; Low, P. J.; Tseng, M.-R.; Lee, G.-H. Inorg. Chem. 2015, 54, 10811-10821.

(16) (a) Li, J.; Djurovich, P. I.; Alleyne, B. D.; Yousufuddin, M.; Ho, N. N.; Thomas, J. C.; Peters, J. C.; Bau, R.; Thompson, M. E. Inorg. Chem. 2005, 44, 1713-1727. (b) Urinda, S.; Das, G.; Pramanik, A.; Sarkar, P. J. Phys. Chem. Solids 2016, 96-97, 100-106. (c) Urinda, S.; Das, G.; Pramanik, A.; Sarkar, P. Com. Theor. Chem 2016, 1092, 32-40.

(17) Phosphorescent complexes with these ligands are rare. For some examples with hydride see: (a) Crespo, O.; Eguillor, B.; Esteruelas, M. A.; Fernandez, I.; García-Raboso, J.; Gómez-Gallego, M.; Martín-Ortiz, M.; Oliván, M.; Sierra, M. A. Chem. Commun. 2012, 48, 5328-5330. (b) Casarrubios, L.; Esteruelas, M. A.; Larramona, C.; Muntaner, J. G.; Oñate, E.; Sierra, M. A. Inorg. Chem. 2015, 54, 10998-11006. (c) Eguillor, B.; Esteruelas, M. A.; Fernández, I.; Gómez-Gallego, M.; Lledós, A.; Martín-Ortiz, M.; Oliván, M.; Oñate, E.; Sierra, M. A. Organometallics 2015, 34, 1898-1910.

(18) Esteruelas, M. A.; López, A. M.; Oliván, M. Chem. Rev. 2016, 116, 8770-8847.

(19) Albrecht, M. Chem. Rev. 2010, 110, 576-623.

(20) Alabau, R. G.; Esteruelas, M. A.; Oliván, M.; Oñate, E.; Palacios, A. U.; Tsai, J.-Y.; Xia, C. Organometallics 2016, 35, 39813995.

(21) Esteruelas, M. A.; López, A. M.; Oñate, E.; San-Torcuato, A.; Tsai, J.-Y.; Xia, C. Organometallics 2017, 36, 699-707.

(22) Esteruelas, M. A.; Fernández-Alvarez, F. J.; Oliván, M.; Oñate, E. Organometallics 2009, 28, 2276-2284.

(23) Wiedner, E. S.; Chambers, M. B.; Pitman, C. L.; Bullock, R. M.; Miller, A. J. M.; Appel, A. M. Chem. Rev. 2016, 116, 8655-8692. 
(24) See for example: (a) Werner, H.; Hohn, A.; Schulz, M. J. Chem. Soc., Dalton Trans. 1991, 777-781. (b) Ghosh, R.; Zhang, X.; Achord, P.; Emge, T. J.; Krogh-Jespersen, K.; Goldman, A. S. J. Am. Chem. Soc. 2007, 129, 853-866. (c) Sola, E.; García-Camprubí, A.; Andrés, J. L.; Martín, M.; Plou, P. J. Am. Chem. Soc. 2010, 132, 9111-9121.

(25) Lin, C.-H.; Chiu, Y.-C.; Chi, Y.; Tao, Y.-T.; Liao, L.-S.; Tseng, M.-R.; Lee, G.-H. Organometallics 2012, 31, 4349-4355.

(26) See for example references: 11d,e 16a and Lamansky, S.; Djurovich, P.; Murphy, D.; Abdel-Razzaq, F.; Kwong, R.; Tsyba, I.; Bortz, M.; Mui, B.; Bau, R.; Thompson, M. E. Inorg. Chem. 2001, 40, 1704-1711.

(27) The substitution of $\mathrm{H}(7)$ by $\mathrm{Ph}(\mathbf{8})$ appears to destabilize the highest molecular orbital (HOMO) of the ligand. As a result, the $\pi$ (alkenyl) $\rightarrow \pi^{*}$ (quinolyl) LLCT transition becomes the lowest-energy transition. See for example: Han, X., Wu, L.-Z., Si, G., Pan, J., Yang, Q.-Z., Zhang, L.-P, Tung, C.-H. Chem. Eur. J. 2007, 13, 1231-1239.

(28) Werner, H.; Schulz, M.; Esteruelas, M. A.; Oro, L. A. J. Organomet. Chem. 1993, 445, 261-265.

(29) John, K. D.; Salazar, K. V.; Scott, B. L.; Baker, R. T.; Sattelberger, A. P. Organometallics 2001, 20, 296-304.

(30) Blessing, R. H. Acta Crystallogr. 1995, A51, 33. SADABS: Area-detector absorption correction; Bruker- AXS, Madison, WI, 1996.

(31) SHELXTL Package v. 6.14; Bruker-AXS, Madison, WI, 2000. Sheldrick, G. M. Acta Cryst. 2008, A64, 112-122.

(32) (a) Lee, C.; Yang, W.; Parr, R. G. Phys. Rev. B 1988, 37, 785-789. (b) Becke, A. D. J. Chem. Phys. 1993, 98, 5648-5652. (c) Stephens, P. J.; Devlin, F. J.; Chabalowski, C. F.; Frisch, M. J. J. Phys. Chem. 1994, 98, 11623-11627.

(33) Grimme, S.; Antony, J.; Ehrlich, S.; Krieg, H. J. Chem. Phys. 2010, 132, 154104.

(34) Gaussian 09, Revision D.01, Frisch, M. J.; Trucks, G. W.; Schlegel, H. B.; Scuseria, G. E.; Robb, M. A.; Cheeseman, J. R.; Scalmani, G.; Barone, V.; Mennucci, B.; Petersson, G. A.; Nakatsuji, H.; Caricato, M.; Li, X.; Hratchian, H. P.; Izmaylov, A. F.; Bloino, J.; Zheng, G.; Sonnenberg, J. L.; Hada, M.; Ehara, M.; Toyota, K.; Fukuda, V; Hasegawa, J.; Ishida, M.; Nakajima, T.; Honda, Y.; Kitao, O.; Nakai, H.; Vreven, T.; Montgomery, Jr., J. A.; Peralta, J. E.; Ogliaro, F.; Bearpark, M.; Heyd, J. J.; Brothers, E.; Kudin, K. N.; Staroverov, V. N.; Keith, T.; Kobayashi, R.; Normand, J.; Raghavachari, K.; Rendell, A.; Burant, J. C.; Iyengar, S. S.; Tomasi, J.; Cossi, M.; Rega, N.; Millam, J. M.; Klene, M. ; Knox, J. E.; Cross, J. B.; Bakken, V.; Adamo, C.; Jaramillo, J.; Gomperts, R.; Stratmann, R. E.; Yazyev, O.; Austin, A. J.; Cammi, R.; Pomelli, C.; Ochterski, J. W.; Martin, R. L.; Morokuma, K.; Zakrzewski, V. G.; Voth, G. A.; Salvador, P.; Dannenberg, J. J.; Dapprich, S.; Daniels, A. D.; Farkas, O.; Foresman, J. B.; Ortiz, J. V.; Cioslowski, J.; Fox, D. J. Gaussian, Inc., Wallingford CT, 2013.

(35) Andrea, D.; Haeussermann, U. M.; Dolg, M.; Stoll, H.; Preuss, H. Theor. Chim. Acta 1990, 77, 123-141.

(36) Ehlers, A. W.; Bohme, M.; Dapprich, S.; Gobbi, A.; Hollwarth, A.; Jonas, V.; Kohler, K. F.; Stegmann, R.; Veldkamp, A.; Frenking, G. Chem. Phys. Lett. 1993, 208, 111-114.

(37) (a) Hehre, W. J.; Ditchfield, R.; Pople, J. A. J. Chem. Phys. 1972, 56, 2257-2261. (b) Francl, M M.; Pietro, W. J.; Hehre, W. J.; Binkley, J. S.; Gordon, M. S.; DeFrees, D. J.; Pople, J. A. J. Chem. Phys. 1982, 77, 3654-3665.

(38) A. V. Marenich, C. J. Cramer, D. G. Truhlar, J. Phys. Chem. B 2009, 113, 6378-6396.

(39) O'Boyle, N. M.; Tenderholt, A. L.; Langner, K. M. J. Comput. Chem. 2008, 29, 839-845.

(40) Qu, X., Liu, Y., Godefroid, G., Si, Y, Shang, X., Wu, X., Wu, Z. Eur. J. Inorg. Chem. 2013, 3370-3383. 


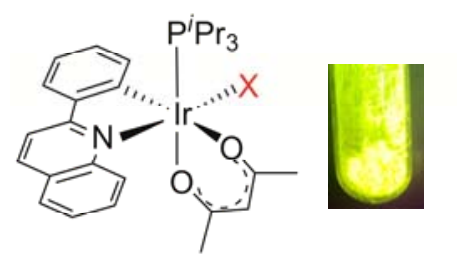

$\underline{\mathrm{CH}=\mathrm{CHPh}}<\mathrm{Cl}<\mathrm{CH}=\mathrm{CH}_{2}<\mathrm{H}$

Quantum efficiency 